\title{
Geochemistry and Petrogenesis of the Banded and Granitic Gneisses in Parts of Kushaka Schist Belt, Northwestern Nigeria
}

\author{
Kehinde Oluyede ${ }^{1} \quad$ Garba Ibrahim $^{1} \quad$ Umar Danbatta $^{1} \quad$ Paul Ogunleye $^{1} \quad$ Urs Klötzli $^{2}$ \\ 1.Department of Geology, Ahmadu Bello University Zaria, Nigeria \\ 2.Department of Lithospheric Research, University of Vienna, Austria
}

\begin{abstract}
The Kushaka schist belt in the Kwona Mutua and Kushaka areas is one of the 12 well recognized N-S trending belts composed of igneous, metamorphic and metasedimentary rocks in varying proportion. The major rocks of the belt comprise the Migmatite-Gneiss-Quartzite Complex, schists and Pan-African granitoids. Banded and granite gneisses constitute the bulk of the Migmatite-Gneiss-Quartzite Complex. Banded gneiss consists of paleosome and leucosome of dioritic, tonalitic, granodioritic and granitic composition while granite gneiss is composed of biotite, staurolite-biotite and staurolite-muscovite gneiss. Major mineral constituents of these rocks are quartz, orthoclase, plagioclase, pyroxene, biotite, muscovite, orthoclase, microcline and staurolite while the accessory minerals are titanite, apatite and iron oxides. Metamorphism may have reached grannulite facies locally with pyroxenes crystallizing in the dioritic and granodioritic rock. Analysis of geochemical data reveals marked variation in the abundance of $\mathrm{SiO}_{2}(60.77-77.53 \mathrm{wt} \%), \mathrm{Al}_{2} \mathrm{O}_{3}\left(12.9-15.99\right.$ wt \%), $\mathrm{Fe}_{2} \mathrm{O}_{3}(0.78-7.04 \mathrm{wt} \%)$, $\mathrm{Na}_{2} \mathrm{O}$ (1.67-5.15 wt\%) and $\mathrm{K}_{2} \mathrm{O}$ (1.64-6.13 wt \%), typical of rocks of hybrid sedimentary-igneous protoliths. Igneous protolith reveals decreasing $\mathrm{P}_{2} \mathrm{O}_{5}$ content with increasing silica content, low $\mathrm{K}_{2} \mathrm{O} / \mathrm{Na}_{2} \mathrm{O}$ ratio $(0.24-$ $0.87)$, low $\mathrm{K}_{2} \mathrm{O}$ values $(<2.5$ wt \%) displaying mixed tholeiitic and calc-alkaline, metaluminous and peraluminous, ferroan and magnesian character, and high-K calc-alkaline to shoshonitic affinities. By contrast, the rocks of sedimentary protolith shows high $\mathrm{K}_{2} \mathrm{O} / \mathrm{Na}_{2} \mathrm{O}$ ratio $(1.19-2.5)$, high $\mathrm{Na}_{2} \mathrm{O}$ values $(>3$ wt \%) and staurolite mineral. Their pelitic and mafic attributes were derived essentially from a quartz-diorite, granodiorite and granite-quartz monzonite source. Fractional crystallization and partial melting of older dioritic-granodioritictonalitic source rock derived from upper mantle materials contaminated by continental crust played important roles during their genesis. They are enriched in Large Ion Lithophile Elements (LILE) but depleted in Nb, P and Ti typical of volcanic arc and syn-collisional settings.
\end{abstract}

Keywords: Banded gneiss, Pan-African, sedimentary, igneous, granodiorite, protolith, Kushaka, Nigeria

DOI: $10.7176 / \mathrm{JEES} / 11-4-05$

Publication date: April $30^{\text {th }} 2021$

\section{INTRODUCTION}

The Nigerian basement complex is part of the Benin-Nigeria shield situated within a Pan-African mobile zone (Fig. 1), and consists of three major rock units: (i) the Migmatite-Gneiss-Quartzite Complex (MGQC), a heterogeneous assemblage of predominantly amphibolite-facies migmatites, orthogneisses, paragneisses, and minor-basic to ultrabasic rocks; (ii) the Schist Belts, believed to overlie the MGQC and consisting mainly of psammitic to pelitic metasediments with interlayered granitoid gneisses and rare amphibolites, interpreted as metavolcanics and (iii) the Older Granites (Turner 1983; Rahaman 1988). The Kushaka schist belt is one of the twelve documented schist belts in Nigeria and characterised by of the presence of low to medium grade metasedimentary, migmatite gneisses and metavolcanic rocks. Migmatites and gneisses of this area belong to the migmatite-gneiss-quartzite complex which are the most widespread rocks and occupy about $30 \%$ of the total surface area of Nigeria, covering half of the "Basement Complex" of Nigeria and probably the least studied of the major rock groups (Rahaman, 1988; Kröner et al. 2001). They are interlayered with amphibolites that were probably derived from Mg-rich rocks such as continental basalts and Pan-African reworkings which led to the recrystallization of minerals from partial melting during medium to upper amphibolite-facies-metamorphism (Caby et al., 1990; Dada, 1999; 2008). Ajibade (1988) distinguished the ancient migmatites in northern Nigeria from the Pan-African migmatites by their complex polyphase deformation and mylonitization.

Kröner et al. (2001) maintained that it has been difficult to define the protoliths of the banded gneisses due to their mixed and complex nature. Some authors suggested that they were metasediments derived from graywacke and shale (Freeth, 1971; Burke and Dewey, 1972), whereas others interpreted them as orthogneisses (Onyeagocha 1986; Ekwere and Ekwueme 1991; Kröner et al., 2001). However, most workers agree that migmatization occurred during upper amphibolite-facies regional metamorphism (Oyawoye, 1972; Onyeagocha and Ekwueme, 1990). There is also consensus that metamorphic segregation, partial melting, and injection of leucogranitic material contributed to the formation of the banded gneisses and migmatites (Kröner et al., 2001).

Based on field and geochemical evidences, the formations of the gneisses in the Nigeria Basement Complex have been attributed to both igneous and sedimentary origin. Burke, et al. (1972) attributed their origin to derivation of isochemical metamorphism of a shale-graywacke sequence while Onyeagocha (1984) proposed an 
igneous origin by partial melting of crustal rocks. According to Rahaman (1988), it is difficult to equivocally distinguish between gneisses of sedimentary and igneous protoliths due to insufficient geochemical data. A study by Dada $(1999 ; 2008)$ reiterated that gneisses and amphibolites in Nigeria form a bimodal association who's petrological and geochemical characteristics indicate a primary igneous origin. Elatikpo et al., (2013) reported that the gneisses in the Malumfashi schist belt in northwestern Nigeria have calc-alkaline affinity and are of igneous origin.

The earlier studies on the gneisses of the migmatite-gneiss-quartzite complex are largely in the southwestern basement of Nigeria (Okonkwo and Ganev, 2012; Elueze et al., 2004; Oyinloye, 1998; 2002; 2004; 2011 and Olarewaju, 1988; Akinola, 2016; Adegbuyi et al., 2017; Ademola and Amos, 2018); with only a few in the northwest (Kröner et al., 2001; Elatikpo et al., 2013; Usman and Ibrahim, 2017). In this work, petrography, major and trace elements data on fifteen relatively unknown banded and granitic gneiss plutons have been used to address the knowledge gaps in the area of provenance, petrogenetic evolution and tectonic setting, and hope it will assist in understanding the evolution of this major rock unit of the Nigeria Basement Complex.

\section{STUDY AREA}

The study area covers a total area of $2,809 \mathrm{~km}^{2}$ and lies within Kushaka and Birnin Gwari schist belts in the north western part of Nigeria. It is bounded by latitudes $10^{0} 15^{\prime \prime} \mathrm{N}$ and $11^{0} 00^{\prime \prime} \mathrm{N}$ and longitudes $6^{0} 30^{\prime}$ ' $\mathrm{E}$ and $7^{0}$ 00" E (Fig. 2) and having Guinea Savannah climatic zone with distinct wet and dry seasons. The area is underlain predominantly by these lithologies: (i) Migmatite-Gneiss-Quartzite suite represented by dioritic, granodioritic, granitic and granitic gneisses with fissile and ferruginous quartzites and Banded Iron Formation (BIF) as well as Kushaka Gneiss Complex represented by extrusive basalts, staurolite and muscovite gneiss and banded iron formation (BIF); the schist belts represented by (ii) Kushaka graphite and sulphur bearing biotite and muscovite quartz schist an inter-banded in places with iron formations and (iv) syn- tectonic and late- orogenic biotitehornblende syenite (BHS) and biotite-hornblende granite (BHG) in the Kushaka schist belt and biotite muscovite granite (BMG) in the Birnin Gwari schist belt area.

\section{MATERIALS AND METHODS}

Thin section of twenty selected representative samples of banded and granitic gneiss were prepared for petrographic studies using a petrographic research microscope at the Department of Geology, Ahmadu Bello University, Zaria. Modal compositions of the rocks were estimated using the JMicrovision software of Nicholas Roduit version 1.2.7. (2002-2008). About $1 \mathrm{~kg}$ each of fifteen samples was broken into pieces with a hammer and crushed into smaller pieces with a jaw-crusher. The samples were thereafter pulverized in a disc mill for about two minutes. Each pulverised sample was thoroughly homogenized to obtain a representative portion which was packaged and thereafter sent to laboratories for whole-rock geochemical analysis in the Department of Lithospheric Research, University of Vienna, Austria. Major oxides were determined by the fused bead method on calcined rock powder fused with lithium tetraborate as flux to form a glass bead. Trace elements used the pressed pellet method directly on the crushed and milled rock powder mixed with polyvinyl alcohol as a binding agent. The element analyses were performed on a sequential X-Ray spectrometer PHILIPS PW2404 using a super-sharp end-window tube with a Rh-anode and a programmable $4 \mathrm{~kW}$ generator $(60 \mathrm{kV}$ max., $125 \mathrm{~mA}$ max.; iso-Watt-switching), with accompanying PANalytical software. Quality assurance and quality control (QA/QC) measure in the analytical technique employ was analysis of four samples of international reference materials for major (SG-1A-Granite, BHVO-2-Basalt) and (GSR-1-Granite, GSR-3-Basalt) trace elements using identical analytical conditions as for the rock samples.

\section{RESULTS}

\subsection{Field Geology and Petrography of banded and grantic gneisses}

The main lithologic units in the study area comprise banded and granitic gneisses. The banded gneiss consists of i) migmatites, ii) paleosome and leucosome (represented by dioritic, tonalitic, granodioritic and granitic composition), and iii) granite gneisses represented by biotite, staurolite-biotite and staurolite-muscovite and granitic gneisses which are product of metasomatism.

\section{Banded Gneiss}

i) Migmatites, referred to as Pan-African migmatite occur as highly jointed and foliated high and low level exposures, with plastic deformation, meso and microscopic fold structure and well preserved $\mathrm{N}-\mathrm{S}$ schistocity. The rock is also characterized by alternating dark bands of biotite and other mafic minerals $(2-6 \mathrm{~cm})$ and light quartzo-fedspathic minerals.

ii) Banded Gneisses occur as thick bands of paleosome and leucosome. They are easily distinguished from the migmatites with their less pervasive $\mathrm{N}-\mathrm{S}$ foliation/fabric. The leucosome is quartzo-feldspathic and occur as 
granitic dykes with minor dextral movement (Fig. 3). Paleosome is ferro-magnesian and of dioritic and granodioritic composition.

Outcrops of the dioritic and granodioritic paleosome are prominent along the Birnin Gwari - Kaduna road around Ungwan Madaki, Gwaska and Kwona Mutua at slightly higher elevation $(569 \mathrm{~m})$. The rock is medium grained and the thick paleosome bands vary from $3 \mathrm{~cm}$ to $10 \mathrm{~m}$, and align parallel to the regional foliation direction (Fig. 3). The rock is composed of augite (55\%), and accessory biotite (5\%) and iron-oxide (5\%) set in a groundmass of quartz (20\%) and plagioclase (15\%). Augite crystals are elongate, curved and branching in subparallel alignment, others occur as group of branching and diverging needles and having different crystallographic orientation to its neighbours. Accessory minerals are apatite, magnetite and iron-oxides (Fig. 4). Granitic leucosome occurs as injections marked by evidence of dextral displacement relative to one another (Fig. 3). Microscopically, the rock consists of hypidiomorphic four to six-sided quartz (30\%) and K-feldspar (40\%) occurring as tabular perthite and microcline with zoned inclusions of dense clay minerals. Plagioclase $(10 \%)$ is tabular, subhedral and zoned, biotite $(10 \%)$ is subhedral and aligned in foliation direction. Iron-oxides $(5 \%)$ occur as accessory. Other accessory minerals are zircon, apatite and magnetite (Fig. 4). Intergrowth textures, such as myrmekite, perthite and micrographic are most common in the study area especially in the leucosome injections (Fig. 4D). Perthite and micrographic textures are characteristics of magmatic origin. Myrmekite microcline intergrowth and K-feldspar overgrowth (K-metasomatism) on plagioclase is also observed in the Gwaska granodiorite (Fig. 4H).

\section{Granitic Gneiss}

iii) Granite gneiss outcrops as high and low level hills. It is generally fine grained, grayish to pink and reddish brown equi-grannular rock. In hand specimen, the rock is composed of quartz, feldspar, biotite and muscovite and it is easily distinguished from the migmatites as it is weakly foliated. The rock differs from banded gneiss because of the absence of thick bands of paleosome and leucosome injections; e. g. the Kampani Doka quarry outcrop. In Gwagwaulu area the granitic gneiss is mainly staurolite-biotite and staurolite-muscovite bearing rock (Fig. 4). Two different types are easily observed on the field. The first type is dark grey medium grained with noticeable N-S foliation and other type is weakly foliated light coloured and fine- to medium grained. The staurolite-biotite granite gneiss occurs as fine to medium grained rock, composed of quartz $(30 \%)$ with intergrowth boundaries, cracks and wavy extinction, $\mathrm{K}$-feldspar $(20 \%)$ is euhedral and elongated, staurolite $(25 \%)$ is pale brown in colour and characterized by quartz inclusions and dotted with iron oxides, biotite $(20 \%)$ is acicular and equally aligned with quartz and staurolite minerals. Iron-ore (5\%) occurs as euhedral and subhedral crystal disseminations. The rock looks like a protomylonite where staurolite porphyroclasts are fragmented and deformed. There has also been alteration in form of chloritization where biotite excretes elongated granules of sphene and needles of rutile (Fig. 4CD). The fragmentation is seen as pervasive cracks in the minerals. Accessory minerals are iron-oxide sphene, apatite, rutile and garnet. The staurolite-muscovite granite gneiss is composed of muscovite (5-10\%) as crystals stacked between the staurolite crystals and embedded in quartz, feldspar and muscovite matrix.

\subsection{Geochemistry Major Oxides}

Whole rock major oxides and trace elements data of the representative samples of migmatite, banded and granitic gneisses are presented in Table 1. The rock samples display a marked variation in the abundance of some major oxides; $\mathrm{SiO}_{2}$ content in the granite ranges from 60.77 to $77.53 \mathrm{wt} \%$. The $\mathrm{SiO}_{2}$ as an index of differentiation (Fig. 5) show that $\mathrm{TiO}_{2}, \mathrm{Fe}_{2} \mathrm{O}_{3}, \mathrm{MgO}, \mathrm{CaO}$ and $\mathrm{P}_{2} \mathrm{O}_{5}$ are all negatively correlated with $\mathrm{SiO}_{2}$ and generally form a well-defined linear trend. The rocks show sub-alkaline affinity, as observed in the total-alkalisilica (TAS) diagram (Cox et al., 1979), where it can be seen that all rocks plot in the sub-alkaline field (Fig. 6A). Based on AFM triangular diagram of Irvin and Baragar, (1971), the rocks are calc-alkaline, however, Gwaska and Ungwan Madaki granodiorite are tholeiitic in character (Fig. 6B). The value of $\mathrm{Fe}_{2} \mathrm{O}_{3} / \mathrm{MgO}<3$ and $\mathrm{TiO}_{2}<1$ are in the range of expectation in calc-alkaline rocks (Irvin and Baragar, 1971; Pearce and Cann, 1973); however, deviations $\left(\mathrm{Fe}_{2} \mathrm{O}_{3} / \mathrm{MgO}\right.$ range $\left.>4\right)$ may suggest close link to basalt; indicating rock of tholeiite series (Miyashiro, 1974). The rocks also have calc-alkaline, high $\mathrm{K}$ calc-alkaline content and shoshonitic affinity as shown in the $\mathrm{K}_{2} \mathrm{O}$ versus $\mathrm{SiO}_{2}$ diagram (Peccerillo and Taylor 1976) (Fig. 6C). The calk-alkaline affinity of the rocks can also be seen in the $\mathrm{Na}_{2} \mathrm{O}+\mathrm{K}_{2} \mathrm{O}-\mathrm{CaO}$ versus $\mathrm{SiO}_{2}$ diagram (Modified Alkaline Lime Index, Frost et al. 2001) (Fig. 6D). The rock samples are also magnesian and slightly ferrous according to the chemical classification proposed by Frost et al. (2001), using the $\mathrm{Fe}_{2} \mathrm{O}_{3} /\left(\mathrm{FeOt}+\mathrm{MgO}\right.$ ) versus $\mathrm{SiO}_{2}$ diagram (Fig. 7A). The ASI vs. A/NK $=\mathrm{Al}_{2} \mathrm{O}_{3} /$ $\left(\mathrm{Na}_{2} \mathrm{O}+\mathrm{K}_{2} \mathrm{O}\right.$ mol \%) of Frost (2001) discriminating diagram has shown that the rock units are ferroan and magnesian, calcic to alkali calcic; and metaluminous to peraluminous in nature (Fig. 7B). The observed metaluminous character $(\mathrm{A} / \mathrm{CNK}<1)$ reflects the presence of calcic minerals, while the samples that yielded $\mathrm{A} / \mathrm{NK}$ in the range of 1.0 to 1.4 is peraluminous and reflects the presence of Na-rich minerals. The major 
element chemistry show some characteristic features such as low $\mathrm{K}_{2} \mathrm{O}$ values $(<2.5 \mathrm{wt} \%)$ and high $(>3 \mathrm{wt} \%)$ $\mathrm{Na}_{2} \mathrm{O}$ values, the 1.6-2.24 value of $\mathrm{Fe}_{2} \mathrm{O}_{3} / \mathrm{MgO}$ ratio and $\leq 1.1$ aluminium saturation index could be an indication of probable arc environment. Also ASI of $<1.1$ ratio is a distinctive chemical property of the I-type granitoids (Chappel and White, 1974). On the discrimination bivariate plot of sedimentary/metasedimentary and igneous series of $\mathrm{Na}_{2} \mathrm{O} / \mathrm{Al}_{2} \mathrm{O}_{3}$ versus $\mathrm{K}_{2} \mathrm{O} / \mathrm{Al}_{2} \mathrm{O}_{3}$ (Garrels and Mackenzie, 1971), the rocks plot within both sedimentary and igneous fields, and at the boundary between the two fields. The $\mathrm{MgO}-\mathrm{CaO}-\mathrm{Al}_{2} \mathrm{O}_{3}$ diagram (Leyleroup, et al., 1977) suggest a sedimentary or igneous origin of the rocks as they plot both within and outside the magmatic field ((Fig. 8 A and B). In the ACF diagram of Winkler (1967), the rocks plot in the field of pelitic rocks. Whearas on the $\mathrm{CaO}-\mathrm{Na}_{2} \mathrm{O}-\mathrm{K}_{2} \mathrm{O}$ diagram (after Condie, 1967), they plot in the field of quartz-diorite and granodiorite, indicating that their pelitic and mafic protoliths were derived essentially from a quartz-dioritic and granodioritic sources (Fig. 9 A and B).

\section{Trace Elements}

Trace elements composition of the banded and granite gneiss and their distribution patterns normalized to average crust are presented in Table 2 and Fig. 12 respectively. The primitive mantle-normalized multi-element diagram (spidergram) (after Sun and McDonough, 1989) shows a more pronounced enrichment in Large Ion Lithophile Elements (LILE) than High Field Strength Elements (HFSE) relatively to the primitive mantle, with marked positive $\mathrm{Ba}, \mathrm{K}, \mathrm{Sr}$ and $\mathrm{Pb}$ anomalies and radioelements ( $\mathrm{U}$ and $\mathrm{Th}$ ). The content of $\mathrm{Ba}$ is very high (453.9 to $2013.33 \mathrm{ppm}$ ), Sr (up to $1027.9 \mathrm{ppm}$ ) Rb (up to $430.1 \mathrm{ppm}$ ) contents. The Sr-Rb-Ba ternary diagram (Fig. 11A) shows a trend towards Ba, known as the HiBaSr trend, typical of high Ba-Sr granitoids (Tarney \& Jones 1994). The granite gneiss in Kungwi and granodiorite in Mando/Birnin Gwari border plot in diorite field; diorite, granodiorite and granitic gneiss plot in quartz diorite field; the granodiorite in Kugu plot in anomalous granite field; the granite gneiss in Kampani Doka and Gwagwaulu plot in normal granite field while the granitic gneiss in Gwaska plot in strongly differentiated granites field (Fig. 11B).

\section{DISCUSSIONS}

In the Kushaka schist belt, field structural relationships and mineralogy of banded and granitic gneiss have shown deformation, magmatic injection, metasomatism and alteration. Geochemical characteristics have also revealed protolith of hybrid igneous and sedimentary origin ( $\mathrm{I}-$ and S-types), as confirmed from the discrimination diagram of Garrels and McKenzie (1971) and Leyleroup et al. (1977); and derived from variable mixing of mantle-derived mafic magma and crustally derived felsic end members, through fractional crystallization and partial melting. Banded gneiss occurs as S-type paleosome with predominant pyroxene minerals, while I-type leucosome injected into the S-type paleosome, with dextral sense of displacement; and characterized by low temperature microcline. On possible source of igneous protolith, the geochemical data on the rocks (Table 1) have revealed that samples of the granitic gneisses are more enriched in $\mathrm{SiO}_{2}$ relative to banded gneiss (67.81 to 77.53). Also $\mathrm{Fe}_{2} \mathrm{O}_{3}$ content is much higher in the banded gneiss than in the granitic gneiss. These trends may suggest diverse protolith and varying degree of fractionation. $\mathrm{Na}_{2} \mathrm{O}$ and $\mathrm{K}_{2} \mathrm{O}$ variations, despite the scattering of these oxide contents show negative and positive correlation respectively with $\mathrm{SiO}_{2}$. These linear trends may reflect the crystal fractionation process in the evolution. Positive $\mathrm{K}$ anomalies result from the abundant presence of alkali feldspar, which can also explain the positive Ba anomalies, element that substitutes $\mathrm{K}$ in alkali feldspars.

The low $\mathrm{K}_{2} \mathrm{O} / \mathrm{Na}_{2} \mathrm{O}$ ratios $(0.24-0.87)$ supports I-type granitic composition. Low $\mathrm{K}_{2} \mathrm{O}(<2.5$ wt \%) content is characteristic of subduction-related granites in continental margin settings, tectonically discriminated as volcanic arc and syn-collision. Enrichment in the mafic oxides correlates positively with their high contents of mafic minerals (biotite, hornblende and pyroxenes). The dominantly magnesian character of these rocks suggests environment of oxidized magmas. Fe content can also reflect basaltic sources of reduced character (Frost et al. 2001). The rocks show sub-alkaline affinity, as observed in the Total-alkali-silica (TAS) diagram of Cox et al. (1979). The observed $\mathrm{Fe}_{2} \mathrm{O}_{3} / \mathrm{MgO}$ range of $1.6-8$ (Table I) is an indication of calc-alkaline and tholeiite affinity and metaluminous and peraluminous character as confirmed in the petrogenetic plots of Irvine and Baragar (1971) and Frost et al. (2001) (Figs. 6A, B and C). The calc-alkaline, high K content and shoshonitic affinity are also characteristic, as shown in the $\mathrm{K}_{2} \mathrm{O}$ versus $\mathrm{SiO}_{2}$ diagram (Peccerillo \& Taylor 1976) (Fig. 6D). Their enriched alumina and radioelement $(\mathrm{Pb}$ and $\mathrm{U})$ most probably reflect the composition of the protolith.

High $\mathrm{K}_{2} \mathrm{O} / \mathrm{Na}_{2} \mathrm{O}$ ratio $(1.19-2.5)$ supports $\mathrm{S}$-type dioritic and granodioritic composition; additionally, high ( $>3$ wt \%) contents of $\mathrm{Na}_{2} \mathrm{O}$ values are characteristics of S-type granite as confirmed by $\mathrm{Na}_{2} \mathrm{O} / \mathrm{Al}_{2} \mathrm{O}_{3}$ versus $\mathrm{K} 2 \mathrm{O} / \mathrm{Al}_{2} \mathrm{O}_{3}$ discrimination diagram (after Garrels and McKenzie, 1971) (Fig. 8A). The $\mathrm{MgO}-\mathrm{CaO}-\mathrm{Al}_{2} \mathrm{O}_{3}$ diagram of (Leyleroup, et al., 1977) confirms the sedimentary origin of some the banded and granitic gneiss as these rocks plot outside the magmatic field (Fig. 8B). In the ACF diagram of Winkler (1967), the banded and granitic gneisses plot as pellitic rocks (Fig. 9A); whereas on the $\mathrm{CaO}-\mathrm{Na}_{2} \mathrm{O}-\mathrm{K}_{2} \mathrm{O}$ diagram (after Condie, 1967), they plot in the field of quartz-diorite, granodiorite and granite-quartz-monzonite, indicating that their shale- 
arkose protoliths were derived essentially from a quartz-diorite, granodiorite source (Fig. 9B). Plots of molar $\mathrm{Al}_{2} \mathrm{O}_{3} /\left(\mathrm{MgO}+\mathrm{Fe}_{2} \mathrm{O}_{3}\right)-\mathrm{CaO} /\left(\mathrm{MgO}+\mathrm{Fe}_{2} \mathrm{O}_{3}\right)$ diagram (after Altherr et al., 2000) also reveals protoliths derived from partial melting of mainly metabasic to tonalitic as well as metagreywacke sources (Fig. 15). High $\mathrm{K}_{2} \mathrm{O}$ / $\mathrm{Na}_{2} \mathrm{O}$ ratio $(0.73-2.77)$ supports $\mathrm{S}$-type dioritic and granodioritic rocks composition which may have resulted from fractional crystallization of basaltic and dioritic mantle material and partial melting with pre-existing metapellitic sedimentary protolith as seen in ACF diagram modified after Winkler (1967).

High $\mathrm{Ba}$ content is consistent with the presence of abundant biotite and feldspars in the rock samples, which is related to plagioclase; biotite and hornblende fractionation (Chappell et al., 1998). Barium tend to remain in the solid phase during partial melting and would be most abundant in the higher melting temperature fractions, while aqueous phases associated with magmatic activity should have relatively low Ba concentrations (Imeokparia, 1981).

The Sr-Rb-Ba ternary diagram (Fig. 11A) shows a trend towards $\mathrm{Ba}$, known as the HiBaSr trend, typical of high Ba-Sr granitoids (Tarney \& Jones 1994). The high proportion of large ion lithophile elements (Ba, Rb, and $\mathrm{Sr}$ ) in the banded and granitic gneisses is due to their incompatibility with the mantle phases (olivine, orthopyroxenes and clino-pyroxenes) thereby concentrating them in the melt that form the parent gneisses. The samples present a negative correlation of $\mathrm{Ba}, \mathrm{Sr}, \mathrm{Nb}, \mathrm{Ni}, \mathrm{Y}, \mathrm{Zr}$ and $\mathrm{Zn}$ with $\mathrm{SiO}_{2}$, (see Fig. 10). This indicates fractional crystallization process in the evolution of migmatites, banded and granitic gneiss. Observed scattered behavior suggests different geological processes, such as mixing or even distinct effects that should be investigated (Rollinson 1993).

The plot of samples in diorite, quartz diorite, anomalous, normal granite and strongly differentiated granites fields on the $\mathrm{Rb}$-Ba-Sr ternary diagram is an indication of diverse nature of protolith. The strongly differentiated granites are those that are distinctly impoverished in $\mathrm{Ba}$ but enriched in $\mathrm{Rb}$. They represent a very late stage of differentiation. "Anomalous granites" are those that have undergone chemical changes (e.g metasomatism) or were not formed by simple mechanism, while "normal granites" are those that are characterized by "normal" distribution of the three index lithophile elements (El Bouseily and El Sokkary 1975). There is relative enrichment in the radioactive elements $\mathrm{U}, \mathrm{Th}$, and radiogenic $\mathrm{Pb}$ (a product of radioactive decay of $\mathrm{Th}$ ) in the rock. Th content is high in mafic S-type granitoids $(11.9-20.6 \mathrm{ppm})$ but low compared to I-type granitoids $(>1-$ $6.6 \mathrm{ppm})$. This could be due to Th being accommodated in the structure of the ferromagnesian minerals. Enrichment in Th is is expected for an incompatible LFSE in a fractional crystallization system (Wyborn, 1983; Chappell, 1998). Negative anomalies of

The trace elements $\mathrm{Nb}, \mathrm{P}$ and $\mathrm{Ti}$ shows negative anomalies and this feature may be related to fractionation of these elements in mineral phases, such as ilmenite, rutile and titanite, which may have remained in the source. $\mathrm{Ti}$ and $\mathrm{Nb}$ are controlled by titanium bearing minerals such as titanite, ilmenite, rutile, garnet and some amphiboles. The negative anomaly in $\mathrm{P}$ is indicative of low content of apatite in the studied rocks. In the I-type granitoids, phosphorus act as a consistent element and fractionation of this element in the early stages of magma crystallization, led to negative anomalies in the crystalized rocks (Atherton and Ghani, 2002).

On the multicationic R1-R2 tectonic discrimation diagram (after Batchelor and Bowden 1985), most rock samples plot in the syn-collision field. However, diorite and some granodiorite and one granite gneiss samples plot in the pre-plate and mantle fractionate field (Fig. 13). Trace elements can also indicate tectonic affinities; on the $\mathrm{Y}+\mathrm{Nb}$ versus $\mathrm{Rb}$ and $\mathrm{Y}$ versus $\mathrm{Nb}$ discrimination diagram after Pearce et al., (1984), banded and granitic gneiss all plotted within the field of post-collision granites and volcanic arc granite (VAG) field (Fig. 14). Low $\mathrm{Th} / \mathrm{U}(\leq 2.5)$ in some of the banded and granitic gneiss suggests mantle affinity as proposed by (Taylor and McLennan, 1985). Plots of molar $\mathrm{Al}_{2} \mathrm{O}_{3} /\left(\mathrm{MgO}+\mathrm{Fe}_{2} \mathrm{O}_{3}\right)-\mathrm{CaO} /\left(\mathrm{MgO}+\mathrm{Fe}_{2} \mathrm{O}_{3}\right)$ diagram (after Altherr et al., 2000), of banded and some granite gneisses agree with differentiation of a mafic magma from an enriched subcontinental lithospheric mantle (Fig. 15).

The origin/formation of gneiss has been a subject of controversy. Oyinloye, (1998) has attributed it a metasedimentary origin while Rahaman, and Ocan, (1978) trace the origin of (e.g. quatzo-feldpathic gneisses) to igneous sources. Elueze and Bolarinwa (2004) opined that it is difficult to propose a single mode of origin for the gneisses in the Nigerian basement due to their variable compositions from location to location; hence geochemical data are to be treated on their own merit as acquired and in conjunction with field report. In the Kushaka schist belt, banded and granitic gneiss are mainly of sedimentary and igneous origin respectively. Granite gneiss is characterized by injection, alteration in form of chloritization, deformation in form of pervasive cracks in the protomylonite staurolite porphyroclasts as well as perthite and micrographic textures; these are evidences of magmatic origin. Banded gneiss on the other hand is characterized by myrmekite, intergrowth and overgrowth of K-feldspar on plagioclase which are evidences of K-metasomatism. Myrmekite is most common in mylonitic gneissose granites and according to Collins (1997), this may have formed by K-metasomatism after deformation processes; this could be true of the mylonites in the adjacent Kusheriki sheet. The banded S-type of dioritic and granodioritic composition and granitic I-type rock may have resulted from fractional crystallization of basaltic and dioritic mantle material and partial melting of metabasic to tonalitic as well as metagreywacke 
and meta-pellitic sedimentary protolith.

\section{CONCLUSION}

Banded and granitic gneisses with diverse nature of protolith form the major lithologic unit of the MigmatiteGneiss-Quartzite basement complex in the Kushaka schist belt; and characterized by deformation, magmatic injection, metasomatism and alteration. Banded gneiss is represented by paleosome and leucosome of dioritic, tonalitic, granodioritic and granitic composition while granite gneiss consists of biotite, staurolite-biotite and staurolite-muscovite gneiss. Plagioclase, pyroxene and biotite fractionation played important roles during their genesis. Staurolite is characteristic for $\mathrm{Al}$ and Fe rich, middle amphibolite-facies rocks (ca. $550-600{ }^{\circ} \mathrm{C}$ ) of sedimentary and igneous origin; however, pyroxenes in the dioritic and granodioritic rocks show that metamorphism may have locally reached grannulite facies. Pelitic and mafic protoliths were derived essentially from a quartz-diorite, granodiorite and granite-quartz monzonite sources. Enrichment in Large Ion Lithophile Elements and radioelements with negative $\mathrm{Nb} \mathrm{P}$ and $\mathrm{Ti}$ anomalies confirms volcanic arc and syn-collisional settings.

\section{ACKNOWLEDGEMENT}

The authors acknowledge the assistance of Mr Adekunle Omokanye as a guide during the field mapping exercise. We are indebted to the staff of Geochronology Laboratory for their efforts in carrying out whole rock major and trace elements analysis. Insights and contributions of Prof. Abba and Prof. Ajibade in the course of this work are greatly acknowledged. The contributions and encouragement of Prof. Najime Tavershima, Head, Geology Department and Dr S. S. Magaji is also acknowledged. Appreciation goes to Mr. A.K. Amuda and Mr E. B. Animashaun of the Department of Geology, Ahmadu Bello University Zaria for thin section preparation and sample pulverization respectively. The help of Peter Nagl, University of Vienna, with the whole rock geochemical analysis is also acknowledged.

\section{REFERENCES}

Adegbuyi, O.1., Ogunyele, A.C., Odindu, M., and Erinfolami, T. (2017). Geochemical Characteristics and Petrogenesis of Basement Rocks in Idoani Area, Ondo State, Southwestern Nigeria. International Journal of Advanced Geosciences, 5 (2), 102-108

Ajaji, T., Weis, D., Giret, A. and Bouabdellah, M. (1998). Coeval potassic and sodic calc-alkaline series in the post-collisional Hercynian Tanncherfi intrusive complex, Northeastern Morrocco: geochemical, isotopic and geochronological evidence. Lithos 45, 371-393.

Ajibade, A. C. 1(988): Structural and tectonic evolution of the Nigerian basement with special reference to NW Nigeria. In International Conference on Proterozoic Geology Tectonics High-Grade Terrains (Ife, Nigeria), pp. $42-129$

Akinola, O.O., Talabi, A.O. and Muhammad, H.R. (2017). Petrostructural features of metaconglomerate in Igarra and Otuo, South-Western Nigeria. Asian Journal of Earth Sciences, 10, 33-43.

Ademola, A.Y., Amos, O.O. (2018). Geology, Geochemistry and Petrogenesis of Precambrian Rocks of Part of Sheet 244 of Ado-Ekiti, Southwestern Nigeria. Journal of Environment and Earth Science Vol.8, No.1,

Altherr, A. Holl, E. Hegner, C. Langer and Kreuzer, H. (2000). High potassium, calc-alkaline I-type plutonism in the European Variscides: northern Vosges (France) and northern Schwarzwald (Germany), Lithos 50 (2000), pp. 51-73.

Atherton, M. P. and Ghani, A. A. 2002. Slab breakoff: a model of Caledonian Late Granite and syn-collisional magmatism in the orthotectonic (metamorphic) zone Scotland and Donegal, Ireland. Lithos 62 (3-4), 65-85

Azevedo, M.R. and Nolan, J. (1998). Hercynian late-post-tectonic granitic rocks from the Fornos de Algodres area (North Central Portugal). Lithos 44, 1-20.

Batchelor, R.A., Bowden, P., 1985. Petrogenetic interpretation of granitoid rock series using multicationic parameters. Chemical Geology 48, 43-55.

Burke, K.C., Freeth, S.J. \& Grant, N.K. (1972). Granitic gneiss in the Ibadan area, Nigeria. In: T.F.J. Dessauvagie and A.J. Whiteman (Eds.) African Geology, University of Ibadan, Nigeria, 103-104.

Condie, K.C. (1967): Geochemistry of early Precambrian grey-wackes from Wyoming. Geochim.Comochim.Acta, 31, 2135-2149.https://doi.org/10.1016/0016-7037(67)90057-9.

Caby, R., Betrand, J.M.L. and Black, R. (1981). Pan-African ocean closure and continental collision in the Hoggar-Iforas segment, central Sahara. In Precambrian Plate Tectonics, A. Kroner (ed.) Elsever Amsterdam, 407-434.

Caby, R., Sial, A., Arthaud, M.H. and Vauchez, A. (1990): Crustal evolution and the Brasiliano orogeny in northeast Brazil. In: Dallmeyer, R. D. \& Lecorche, J. P. (eds) The West African orogens and circumAtlantic correlatives. Springer Verlag, New York, pp. 373-397. 
Collins, L. G., 1997a, Replacement of primary plagioclase by secondary K- feldspar and myrmekite: ISSN 15265757, Electronic Internet Publication, No. 2, http://www.csun.edu/ vcgeo005/Nr2Myrm.pdf.

Cox, K.G., Bell, J.D., Pankhurst, R.J., (1979). The interpretation of igneous rocks, George, Allen and Unwin, London.

Chappell, B.W and White, A.J.R. (1974): Two contrasting granite types. Pacific journal geology. 8, 173.174.

Chappell, B.W and White, A.J.R. (1992): I- and S-type granites in the Lachlan Fold Belt. Journal of Earth Science 83, 1-26.

Chappell B.W. and Stephens W.E. (1974). Origin of infracrustal (I-type) granite magmas. Transactions of the Royal Society of Edinburgh: Earth Sciences 79, 71-86.

Chappell B. W. (1996) Compositional variation within granite suites of Lachlan Fold Belt: its causes and implications for the physical state of granite magma. Transactions of the Royal Society of Edinburgh: Earth Sciences 88, 159-170.

Chappell B.W. Bryant, C.J., Wyborn, D., White A.J.R and Williams I.S. (1998). High- and low-temperature Itype granites. Resource Geology 48, 225-226.

Chen Y.D., Price, R.C., and White, A.J.R. (1990). Mafic inclusions from the Glenborg and Blue Gum granite suites, southeastern Australia. Journal of Geophysical Research 95, 17757 - 17785.

Dada, S. S. (1998). Crust-forming ages and Proterozoic crustal evolution in Nigeria: of current interpretations. Precambrian Research 87, 65-74.

Dada, S.S. (1999). Geochemistry and petrogenesis of the reworked Archaean gneissic complex of north-central Nigeria: major and trace element studies on Kaduna amphibolites and migmatitic gneisses. Global Journal of Pure and Applied Science, 5, 535-543.

Dada, S.S. (2008): Proterozoic Evolution of the Nigeria-Borborema Province,” In: R. J. Pankhurst, R. A. Trouw, B. B. Brito Neves and M. J. De Wit, Eds., West Gondwana: Pre-Cenozoic Correlations across the South Atlantic Region, Geological Society of London Special Publication, London, 121-136

Deer, W.A., Howie, R.A. and Zussman, J. (1992). An Introduction to the Rock Forming Minerals. Second Edition, Longman Group, Hong Kong.

Ekwere, S.J., Ekwueme, B.N., (1991): Geochemistry of Precambrian gneisses in the eastern part of the Oban massif, southeastern Nigeria. Geologie Mijnbouw 70: 105-114.

Elatikpo, S.M., Danbatta, U.A. \& Najime, T. (2013). Geochemistry and Petrogenesis of Gneisses Around KafurYari Bori-Tsiga area within the Malumfashi Schist Belt, North-western, Nigeria. Journal of Environment and Earth Science, 3(7), 171 - 180.

El Bouseily, A.M and El-Sokkary, A.A. (1975). The relationship between $\mathrm{Rb}, \mathrm{Sr}$ and $\mathrm{Ba}$ in granitic rocks. Chemical Geology. 16, 174-189

Elueze, A.A. \& Bolarinwa, A.T. (2004). Petrochemistry and Nigeria. Journal of Mining and Geology, 40(1), 1-8.

Ewart, A. and Griffin, W.L. (1994). Application of proton-microprobe data to trace-element partitioning in volcanic-rocks. Chemical Geology. 117 (1-4) 251-284.

Ferre, E.C, Deleris, J, Bouchez, J.L, Lar, A.U., and Peucat, J.J (1996): The Pan-African Reactivation of Eburnean and Archaen Provinces in Nigeria: Structural and Isotopic Data. In: Journal of the Geological Society, London, 153: 719-728.

Freeth S.J., (1971): Geochemical and related studies of West African igneous and metamorphic rocks. Doctoral dissertation, University of Ibadan unpublished pp. 228-231

Frost, B.R., Barnes, C.G., Collins, W.J., Arculus, R.J., Ellis, D.J., and Frost, C.D. (2001): A geochemical classification for granitic rocks. Journal of Petrology, (42): 2033-2048

Garrels, R.M. \& Mackenzie, F.T. (1971). Evolution of sedimentary rocks. W.W. Norton and Company, Incorporated. New York, 394p.

Gardien, V., Thompson, A.B., Grujic, D. and Ulmer, P. (1995). Experimental melting of biotite + plagioclase + quartz \pm muscovite assemblage and implications for crustal melting, Journal of Geophysical Research 100, $15581-15591$.

Grigoriev, S.I. and Pshenichny, C.A. (1998). Late Mesozoic post-collisional intermediate to silicic magmatism in the Badjal area, far east of Russia. Lithos 45, 457-468.

Harrison, T.N., 1990. Chemical variation in micas from the Cairngorm pluton, Scotland. Mineralogical Magazine 52, 355-366.

Imeokparia, E. G., (1981). $\mathrm{Ba} / \mathrm{Rb}$ and $\mathrm{Rb} / \mathrm{Sr}$ ratios as indicators of magmatic fractionation, postmagmatic alteration and mineralization- Afu Younger Granite Complex, Northern Nigeria. Geochemical Journal 15, 209-219.

Irvine, T.N., and Baragar, W.R.A. (1971). A Guide to the Chemical Classification of Common Volcanic Rocks. Canadian Journal of Earth Sciences, 8, (5), 523-548. doi:10.1139/e71-055 
Kröner, A., Ekwueme, B.N. and Pidgeon, R.T. (2001). The Oldest Rocks in West Africa: SHRIMP Zircon Age for Early Achean Migmatitic Orthogneiss at Kaduna, Northern Nigeria. Journal of Geology, university of Chicago, 109, 399-406.

Leyleroup, A., Duppy, C., and Andriambolona, R. (1977): Chemical composition and consequence of the evolution of the French Massif Central Precambrian crust. Contribution Mineralogy and Petrology, 62 , 283-300.

Mason, B., 1982. Principles of geochemistry (Smith and Wyllie Intermediate Geology Series), $4^{\text {th }}$ Ed. John Wiley, New York, 310.

McDonough, W. F., (1991). Chemical and isotopic systematic of continental lithospheric mantle. In: Kimberlites, Related Rocks and Mantle Xenoliths. Meyer, H. O. A. and Leonardos, O. H. (Editors), Companhia de Pesquisa de Recursos Minerals, Rio de Janeiro. 1: 478-485.

Nono G.D.K., Nzenti J.P., Suh C.E., Ganno S. (2010). Geochemistry of ferriferous, high-K calc-alkaline granitoids from the Banefo-Mvoutsaha Massif (NE Bafoussam), Central Domain of the Pan- African Fold Belt, Cameroon. The Open Geology Journal, 4:15-28.

Onyeagocha A.C. (1986): Geochemistry of basement granitic rocks from north central Nigeria. Journal of African Earth Science 5(2), 651-657.

Oyawoye, M.O. (1972): The basement complex of Nigeria. In Dessauvagie, T. F., and Whiteman, A. J., eds. African geology. Ibadan, Geology Department, University of Ibadan, pp. $42-98$

Onyeagocha, A.C. and Ekwueme, B.N. (1990). Temperature-pressure distribution patterns in metamorphosed rocks of the Nigerian Basement Complex-a preliminary analysis. Journal of African Earth Sciences 11, 83-93.

Onyeagocha, A.C. (1984). Petrology and geologic history of north-western Akwanga area in northern Nigeria. Journal of African Earth Sciences, 2(1), 41-51.

Okonkwo, C.T and Ganev, V.Y. (2012). U-Pb Geochronology of the Jebba Granitic Gneiss and its Implications for the Paleoproterozoic Evolution of Jebba Area, Southwestern Nigeria. International Journal of Geosciences, 3, 1065-1073

Oyinloye, A.O. and Ojo, A.O.(1988). Physical and Mineral Evaluation of lay Deposits at Ado-Ekiti. Journal of Techno-Science, (2) 1, 49-52.

Oyinloye, A.O. (1998). Geology, Geochemistry and origin of granite gneisses in the basement complex of the Ilesha area Southwest Nigeria. Journal of African Earth Sciences, 26(4), 633-641.

Oyinloye, A.O. (2002). Geochemical characteristics of some granite gneisses in Ilesha area: Implication on the evolution of the Ilesha Schist belt S. W. Nigeria, Trends in Geochemistry India (2) 59 - 71.

Oyinloye, O.A. (2011). Geology and Geotectonic Setting of the Basement Complex Rocks in Southwestern Nigeria: Implications on Provenance and Evolution, Earth and Environmental Sciences, http://www.intechopen.com/books/earthand-environmental-sciences.

Oyinloye,A.O. (2004): Petrochemistry, pb isotope systematic and geotectonic setting of granite gneisses in Ilesha schist belt southwestern Nigeria. Global Journal of Geological Science, 2(1), 1-13.

Olarewaju, V.O. (1988). "Petrology and geochemistry of the charnockitic and associated granitic rocks of AdoEkiti, Akure, S.W. Nigeria”. In: Precambian Geology of Nigeria. 231-239. Geological Survey of Nigeria Publication.

Partino Douce, A.E. and Beard, J.S. (1995). Dehydratation-melting of biotite gneiss and quartz amphibolite from 3 to 15 kbar, Journal of Petrology 36, 707-738.

Partino Douce, A.E. and Beard, J.S. (1996). Effects of $\mathrm{P}, \mathrm{f}\left(\mathrm{O}_{2}\right)$ and $\mathrm{Mg} / \mathrm{Fe}$ ratio on dehydratation melting of model metagreywackes, Journal of Petrology 37, 999-1024.

Pearce, J. A. Harris, N. B. W. and Tindle, A. G. W. 1984. Trace Element Discrimination Diagrams for the Tectonic İnterpretation of Granitic Rocks. Journal of Petrology, 25, (4), 956-983.

Peccerillo, A., and Taylor, S.R. (1976). Geochemistry of Eocene calc-alkaline volcanic rocks from the Kastamonu area, northern Turkey. Contributions to Mineralogy and Petrology, 58, 63-81.

Pollard, P.J., Nakapandungrat, S. and Taylor, R.G., (1995). The Phuket Supersuite, southwest

Thailand: fractionated I-type granites associated with Tin-Tantalum mineralization. Economic Geology 90, 585602.

Rahaman, M. A. (1988). Recent advances in the study of the basement complex of Nigeria. In: Precambrian Geology of Nigeria. (Eds. Oluyide et al.) a publication of the Geol. Surv. Nigeria. 71-43.

Rahaman, M. A and Ocan, O. O. (1978): On relationship in the Precambrian migmatitic gneisses of Nigeria J. Min. and Geol. Vol. 15, No.1 (abs).

Roberts, M.P. and Clemens J.D. (1993). The origin of high-potassium calc-alkaline I-type granitoids. Geology 21, $825-828$

Rollinson, H. R., 1993. Using Geochemical Data: Evaluation, Presentation and Interpretation. Longman Group, Uk Ltd. Co-published in the United States with John Wiley and Sons, New York, 352. 
Rottura, A., Bargossi, G.M., Caggianeli, A., Del Moro, A., Visona, D. and Tranne, C.A. (1998). Origin and significance of the Permian high-K calc-alkaline magmatism in the central-eastern Southern Alps, Italy. Lithos 45, (1-4) 329-348.

Singh, J. and Johanneses, W. (1996). Dehydration melting of tonalites: Part II. Composition of melts and solids, Contributions to Mineralogy and Petrology 125, 26-44.

Sun S.S. and McDonough W.F. (1989). Chemical and isotopic systematics of oceanic basalts: implications for mantle composition and processes. In: Saunders A.D., Norry M.J. (Eds.). Magmatism in the ocean basins. Geological Society of London, Special Publication, 42:313-345.

Sun, L.M. and Chen, J.C. (1992) Geochemical study of granites from Chimen (Quemoy) and Hong Kong, Southeastern China. Journal of Southeast Asian Earth Sciences 7, (4), 237-245.

Tarney J. \& Jones C.E. (1994). Trace element geochemistry of orogenic igneous rocks and crustal growth models. Journal of the Geological Society, 151(5):855-868.

Taylor, S.R. and McLennan, S. M. (1985): The Continental Crust: its Composition and Evolution". Blackwell Scientific Publications, 85, 34-88

Truswell, J.F. and Cope, R.N. (1963). The geology of parts of Niger and Zaria Provinces, Northern Nigeria. Bulletin Geological Survey Nigerian 29, 38.

Tubosun, I.A., Lancelot, J.R., Rahaman, M.A., Ocan, O. (1984). U-Pb Pan-African ages of two charnockitegranite association from southwestern Nigeria. Contribution to Mineralogy and Petrology 88, 188-195.

Turner, D.C. (1983). Upper Proterozoic schist belts in the Nigerian sector of the Pan African Province of West Africa. Precambrian Research 21, 5-79.

Usman, M.A. and Ibrahim, A.A. (2017). Petrography and Geochemistry of Rocks of Northern Part of Wonaka Schist Belt, Northwestern Nigeria. Nigerian Journal of Basic and Applied Science. 25(2): 87-99.

Winkler, H.G.F. (1967): Petrogenesis of Metamorphic Rocks. $2^{\text {nd }}$ Edition. Springer Verlag, New York, 237p. https://doi.org/10.1007/978-3-662-00866-9.

Wolf, M.B. and Wyllie, J.P. (1994). Dehydration-melting of amphibolite at 10 kbars: the effects of temperature and time. Contributions to Mineralogy and Petrology 115, pp. 369-383.

Wyborn, D. (1983). Fractionation processes in the Boggy Plain Zoned Pluton. Ph.D. Thesis. Australian National University, Canberra (Unpublished).

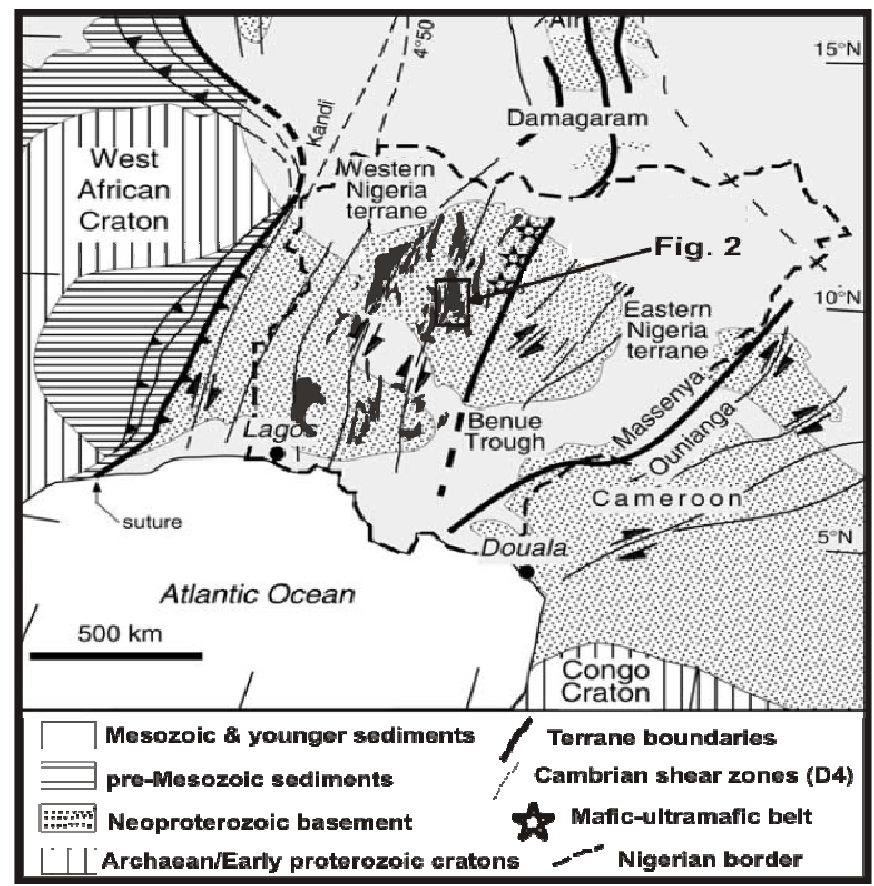

Fig. 1: Geological sketch map of terrane amalgamation between the cratons of west Africa and Congo block. Modified after Ferre et al. (1996) 


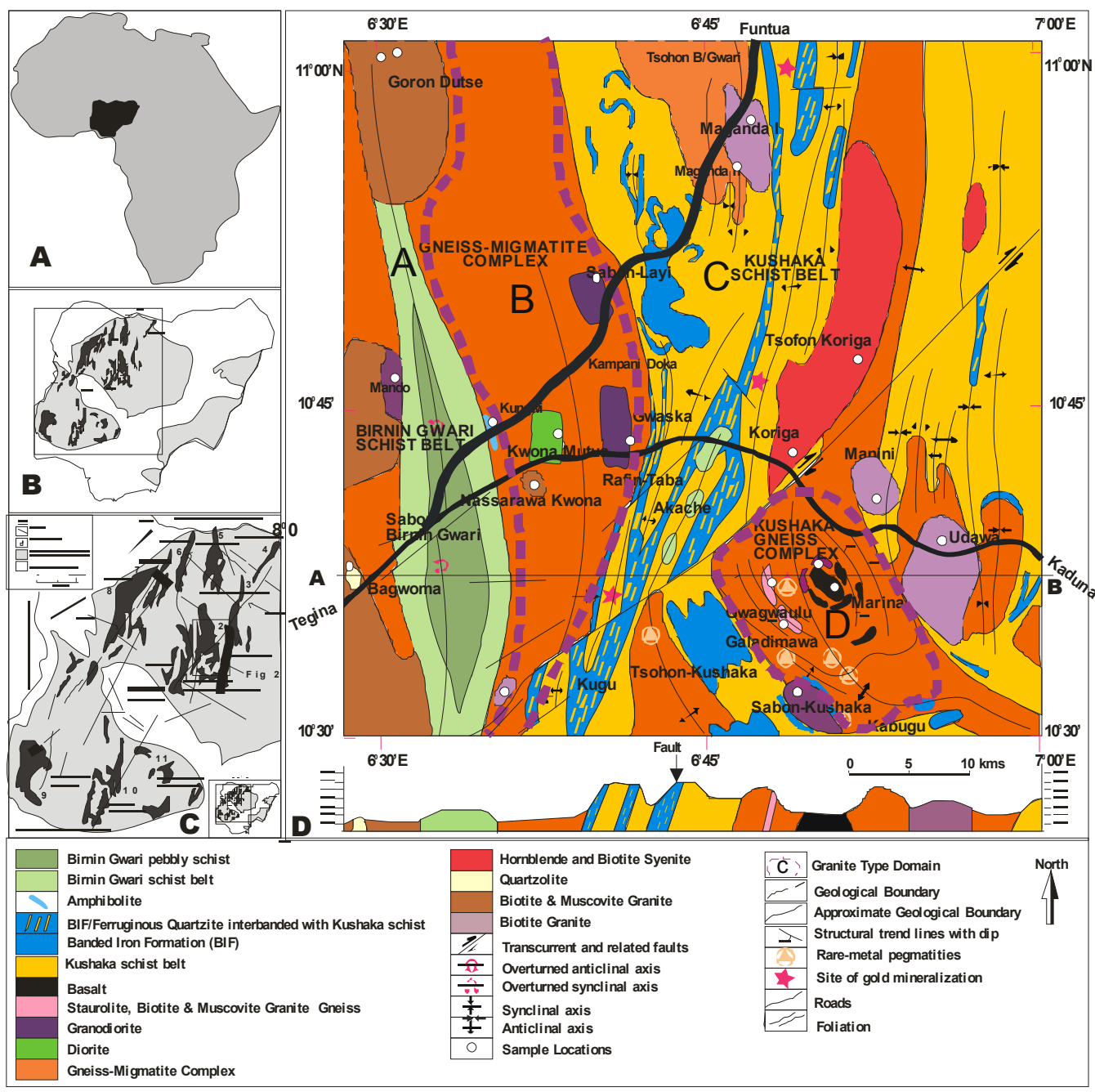

Fig. 2: Geological map of northern part of Kushaka and Birnin Gwari schist belts (Sheet 122) Modified after Truswell and Cope, (1963). 

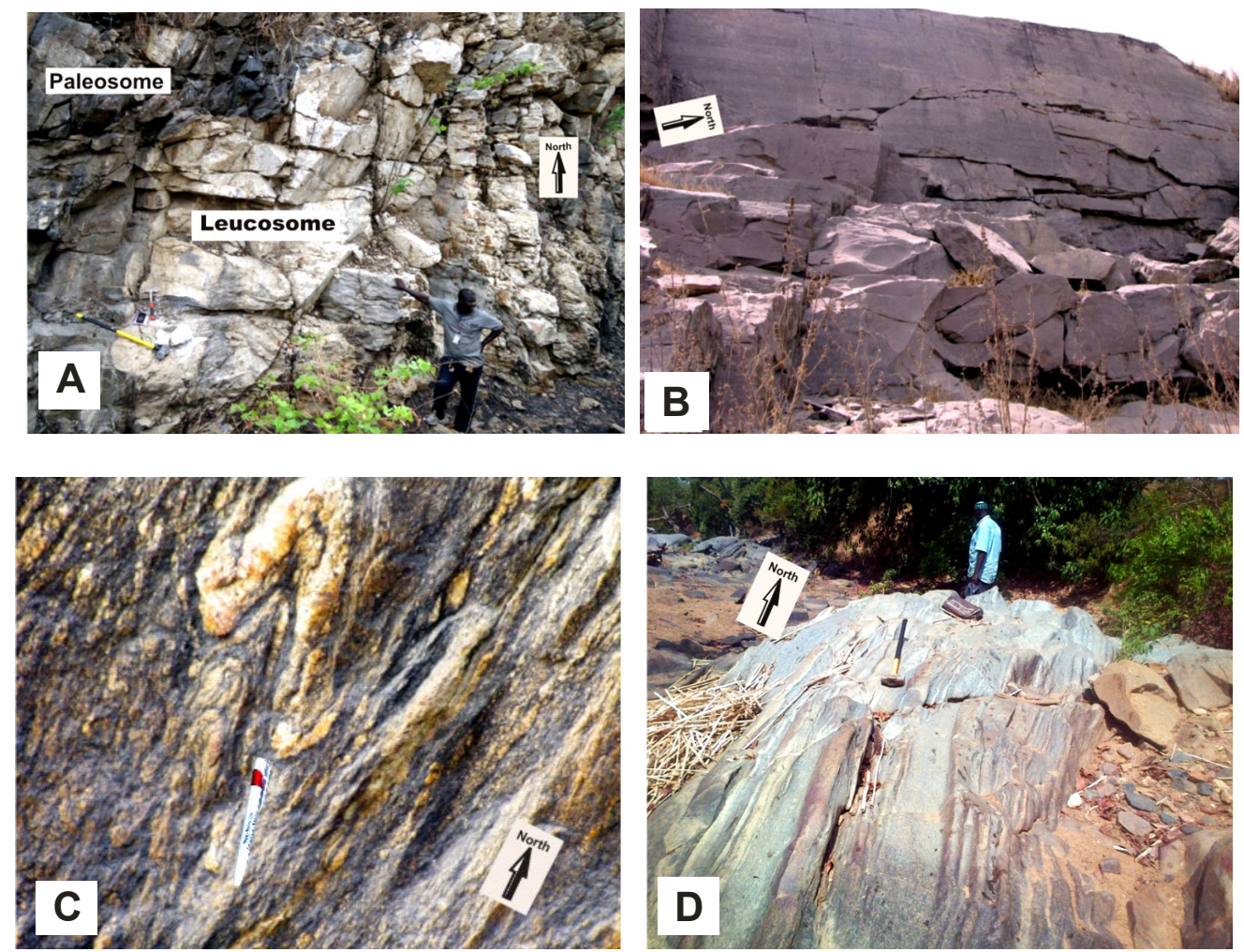

Fig. 3: Field occurrence of (A): migmatite paleosome and leucosome (injection) in Gwaska (N10 43, 40" E $6^{0}$

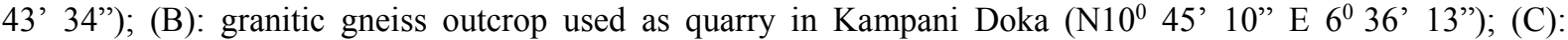

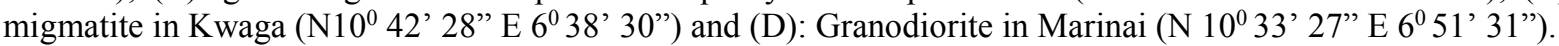



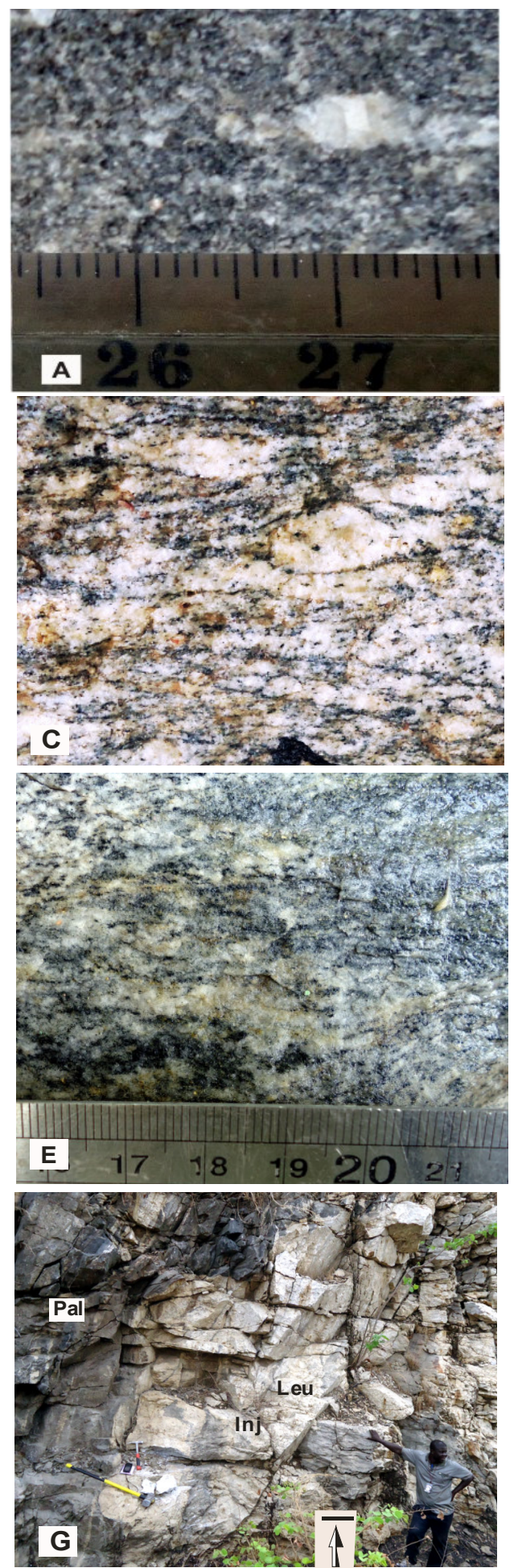
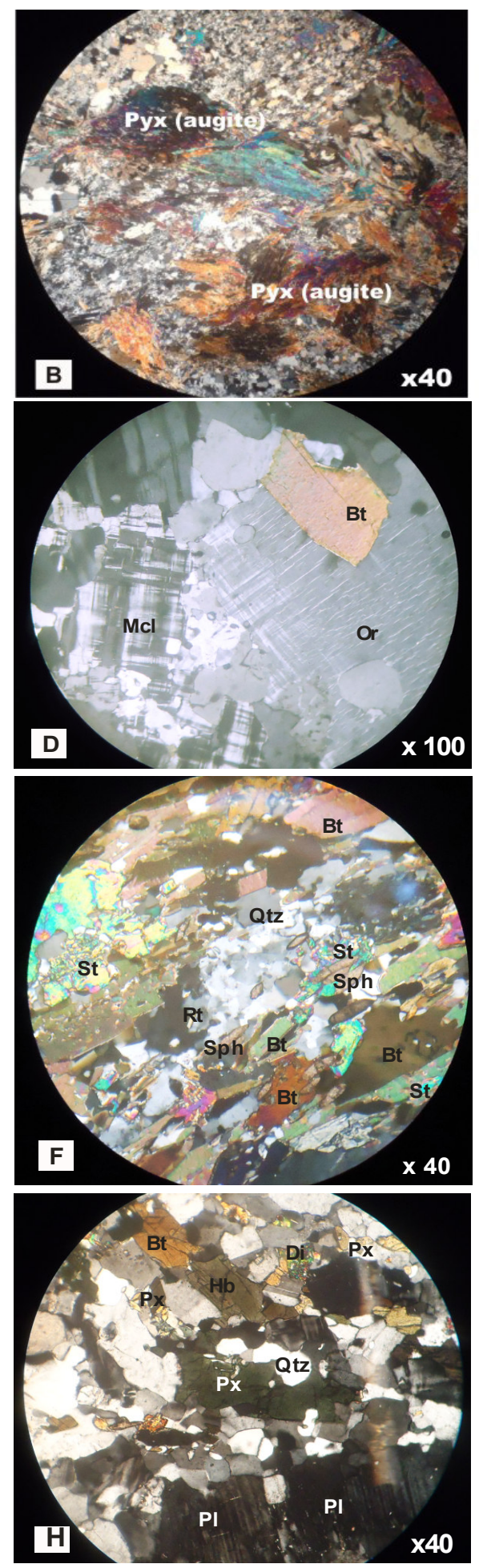

Fig. 4: Hand Specimen and Photomicrograph of $\mathrm{AB}$ ): Dioritic rock (paleosome) in Ungwan Madaki; $\mathrm{CD}$ : Granitic leucosome in Gwaska; EF: Staurolite and biotite gneiss in the Kushaka Gneiss Complex and GH: Granodioritic (paleosome) in Gwaska $(\mathrm{Qtz}=\mathrm{Quartz}, \mathrm{Mcl}=$ Microcline, Or=Orthoclase, Bt=Biotite, $\mathrm{St}=\mathrm{Staurolite}$, $\mathrm{Sph}=$ Sphene) . 

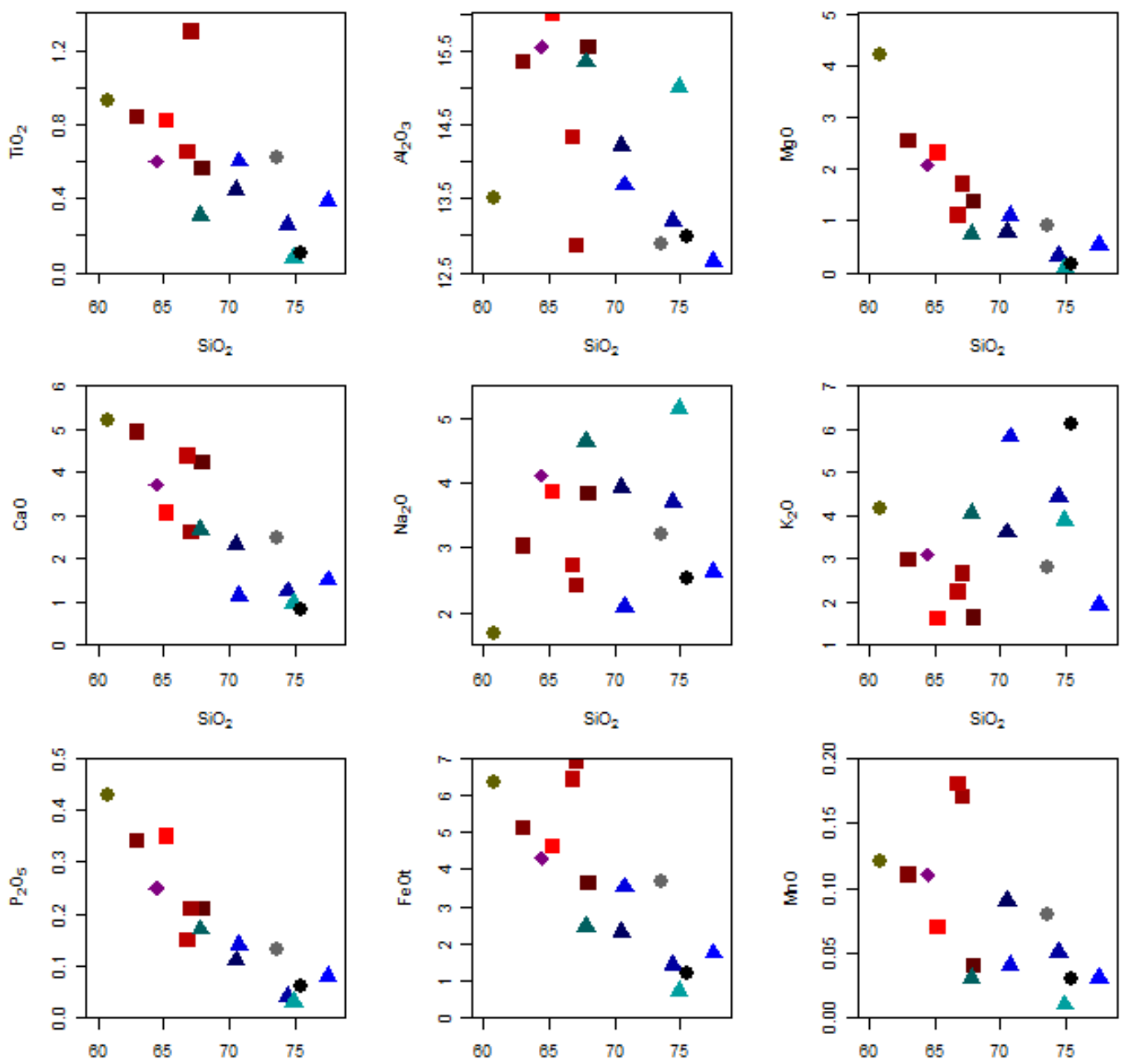

$\mathrm{SiO}_{2}$

$\mathrm{SiO}_{2}$

$\mathrm{SiO}_{2}$

1 Banded Gneiss (Paleosome)

$\triangle$ Granite Gneiss (Paleosome)

Granite (leucosome)

Fig. 5: Harker variation diagrams; silica $\left(\mathrm{SiO}_{2} \mathrm{wt} \%\right)$ plotted against a range of major (in wt \%) elements in the granitoids of the Kushaka schist belt 

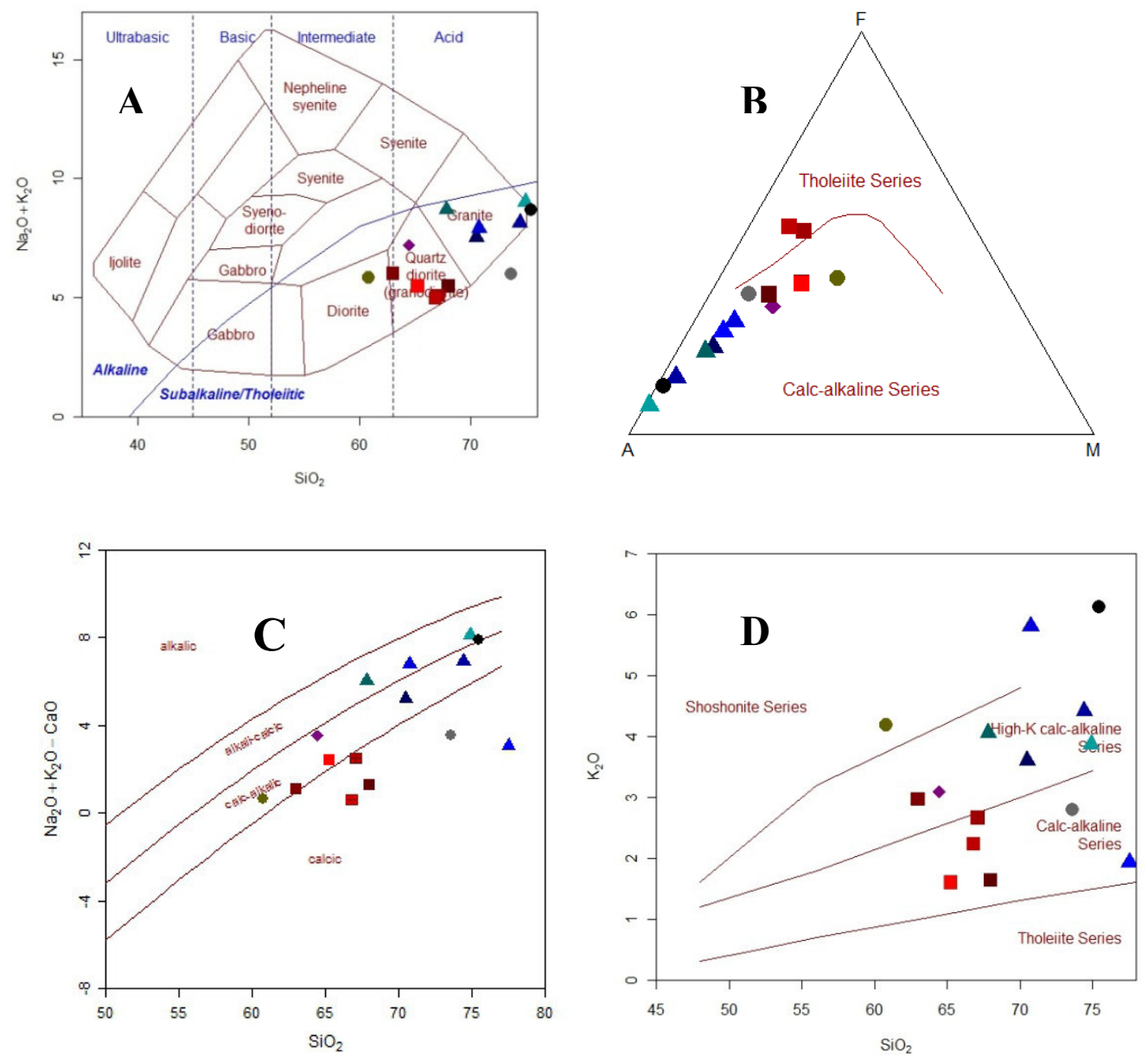

Fig. 6: (A) $\mathrm{SiO}_{2}$ versus $\mathrm{Na}_{2} \mathrm{O}+\mathrm{K}_{2} \mathrm{O}$ diagram (after Cox et al., 1979) with the curve to distinguishing alkaline from subalkaline magmatic series. (B) AFM diagram (after Irvine and Bargar, 1971). (C) $\mathrm{Na}_{2} \mathrm{O}+\mathrm{K}_{2} \mathrm{O}-\mathrm{CaO}$ versus $\mathrm{SiO}_{2}$ diagram (after Frost et al., 2001) discriminating calcic to alkali-calcic. (D) $\mathrm{K}_{2} \mathrm{O}$ versus $\mathrm{SiO}_{2}$ diagram (after APeccerillo \& Taylor 1976) (Symbols as in Fig. 3). 

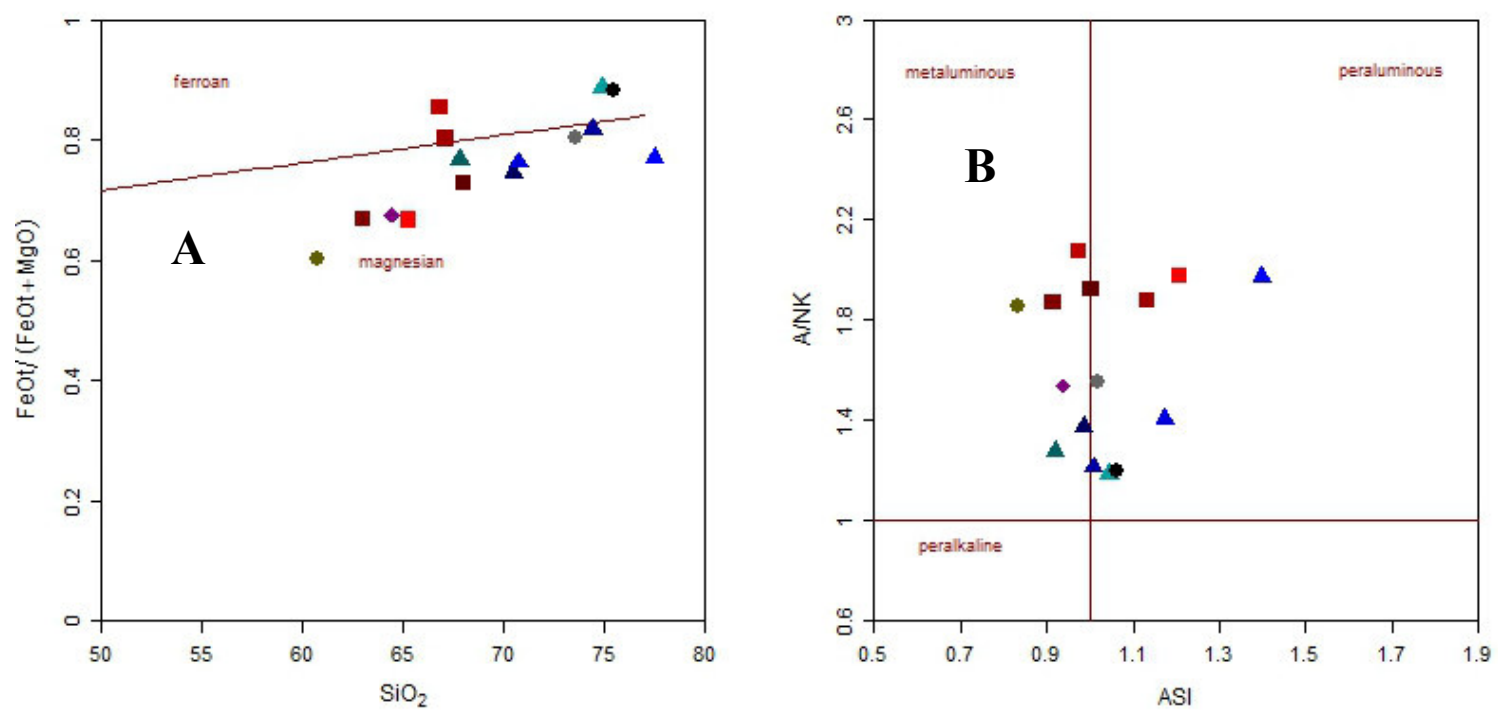

Fig. 7: (A) $\mathrm{SiO} 2$ versus $\mathrm{Fe}_{2} \mathrm{O}_{3}\left(\mathrm{Fe}_{2} \mathrm{O}_{3}+\mathrm{MgO}\right)$ discriminating ferroan and magnesian field. (B) ASI vs. $\mathrm{A} / \mathrm{NK}=$ $\mathrm{Al}_{2} \mathrm{O}_{3} /\left(\mathrm{Na}_{2} \mathrm{O}+\mathrm{K}_{2} \mathrm{O}\right.$ mol \%) diagram of Frost et al., (2001) discriminating metaluminous to reraluminous field (Symbols as in Fig. 3).

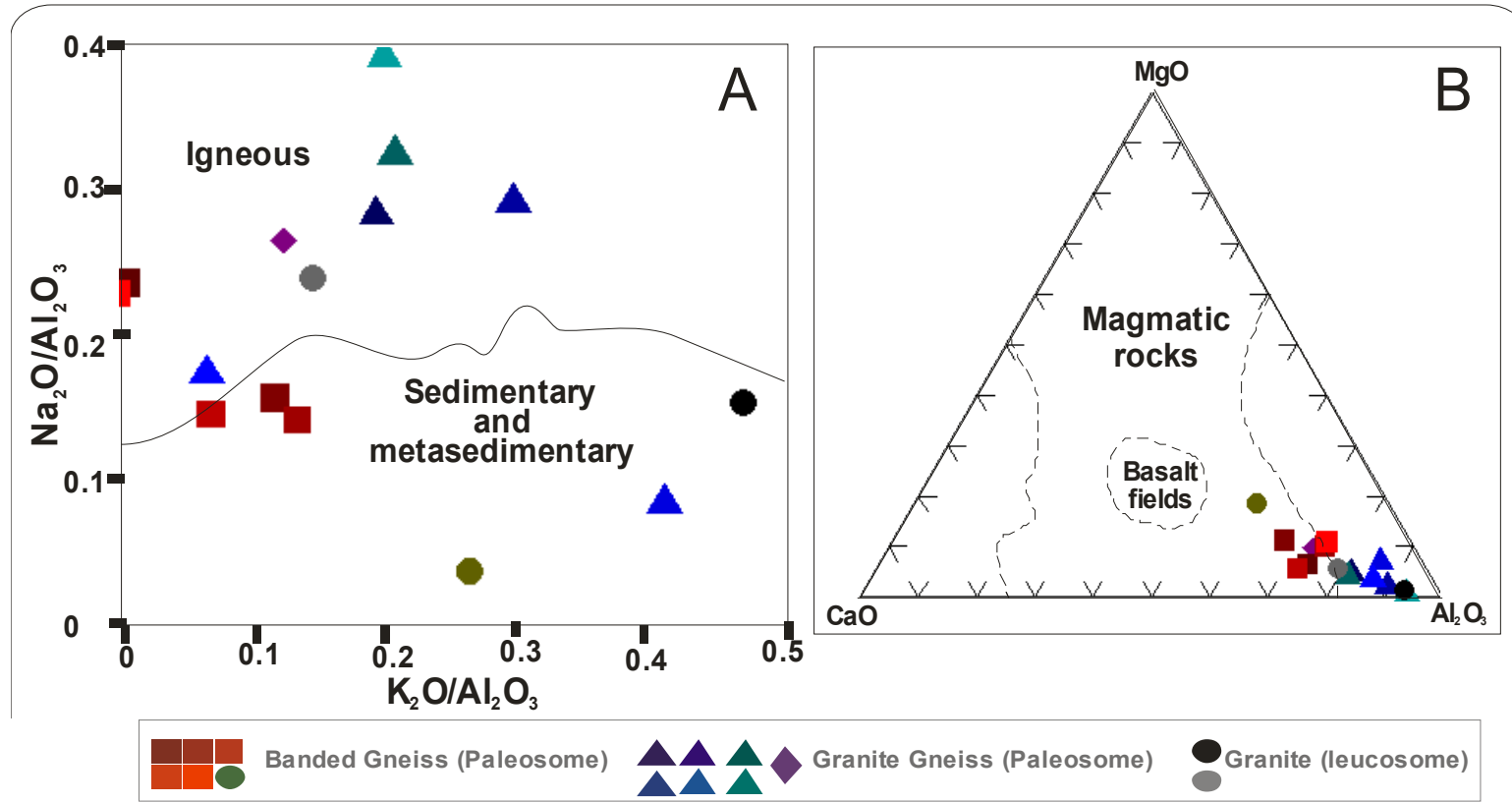

Fig. 8: (A) $\mathrm{Na}_{2} \mathrm{O} / \mathrm{Al}_{2} \mathrm{O}_{3}$ versus $\mathrm{K}_{2} \mathrm{O} / \mathrm{Al}_{2} \mathrm{O}_{3}$ discrimination diagram (after Garrels and McKenzie, 1971) and (B) $\mathrm{MgO}-\mathrm{CaO}-\mathrm{Al}_{2} \mathrm{O}_{3}$ diagram for migmatites, banded and granitic gneisses in Kushaka area (after Leyleroup et al., 1977). 

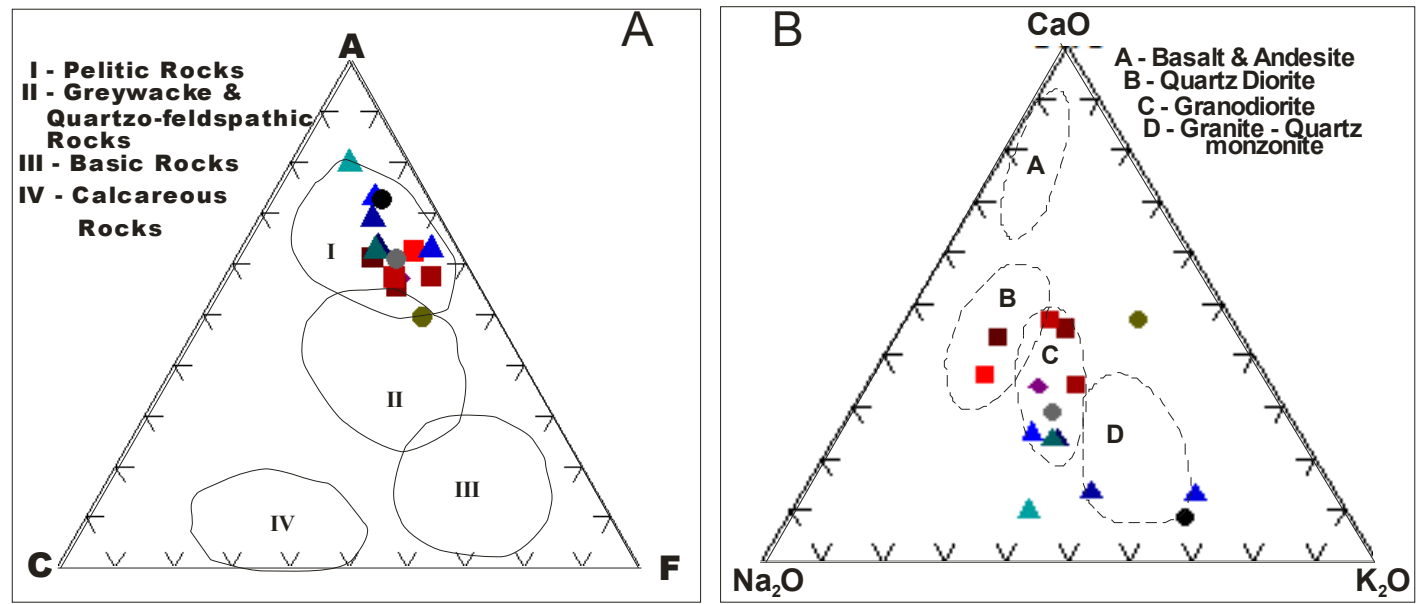

Banded Gneiss (Paleosome)

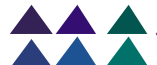

Granite Gneiss (Paleosome)

Granite (leucosome)

Fig. 9: (A) ACF diagram (modified after Winkler, 1967) and (B) $\mathrm{CaO}-\mathrm{Na}_{2} \mathrm{O}-\mathrm{K}_{2} \mathrm{O}$ ternary diagram for migmatites, banded and granitic gneisses in Kushaka area (after Condie, 1967)
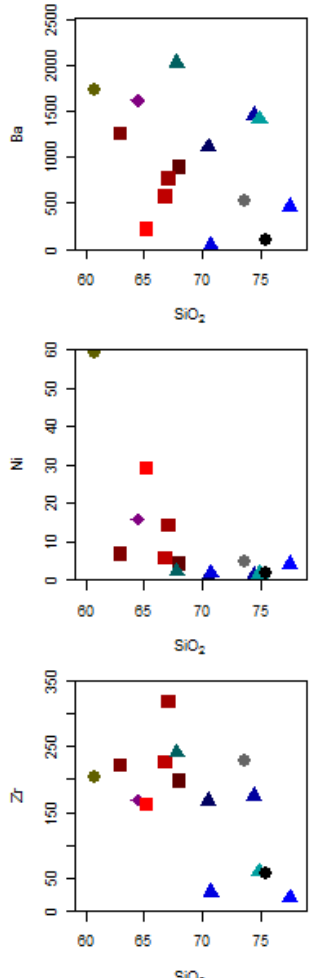

$\mathrm{SiO}=$

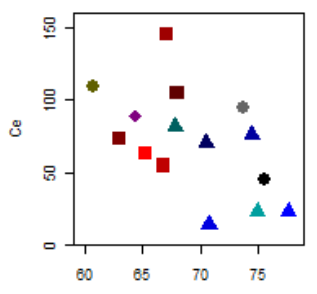

$\mathrm{SiO}_{2}$

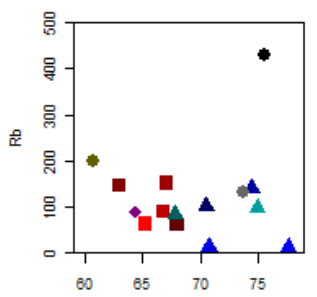

$\mathrm{SiO}_{2}$

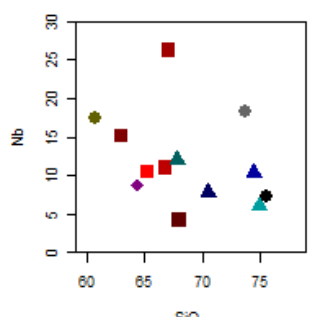

$\mathrm{SiO}_{2}$

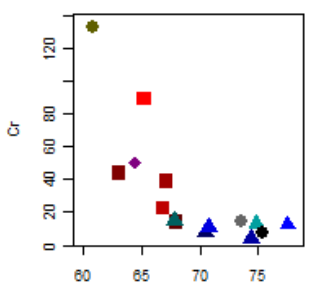

$\mathrm{SiO}_{2}$
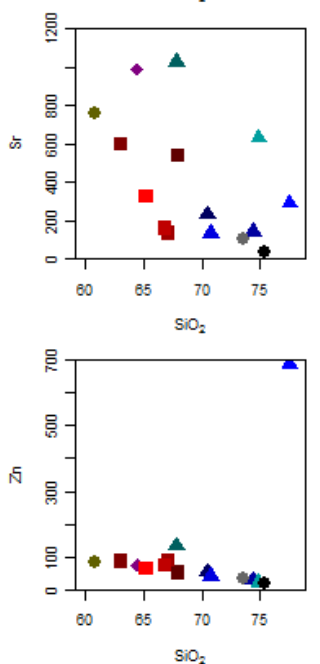

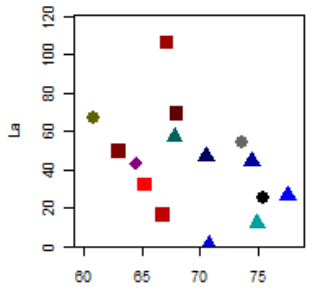

$\mathrm{SiO}_{2}$

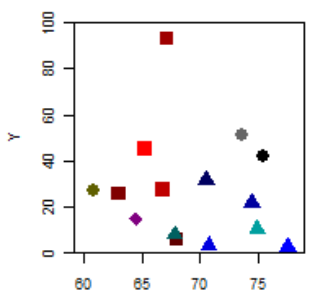

sio.

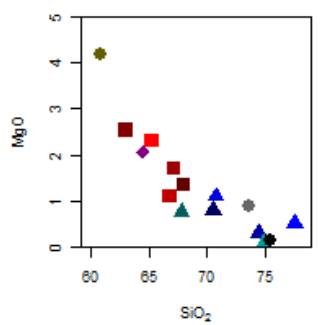

Fig. 10: Multiple plot of silica ( $\mathrm{SiO} 2)$ plotted against a range of selected trace elements $(\mathrm{Ba}, \mathrm{Ce}, \mathrm{Cr}, \mathrm{La}, \mathrm{Ni}, \mathrm{Rb}$, $\mathrm{Sr}, \mathrm{Y} \mathrm{Zr} \mathrm{Nb}, \mathrm{Mg}$ ) for the migmatite banded and granitic gneisses (Symbols as in Fig. 3). 

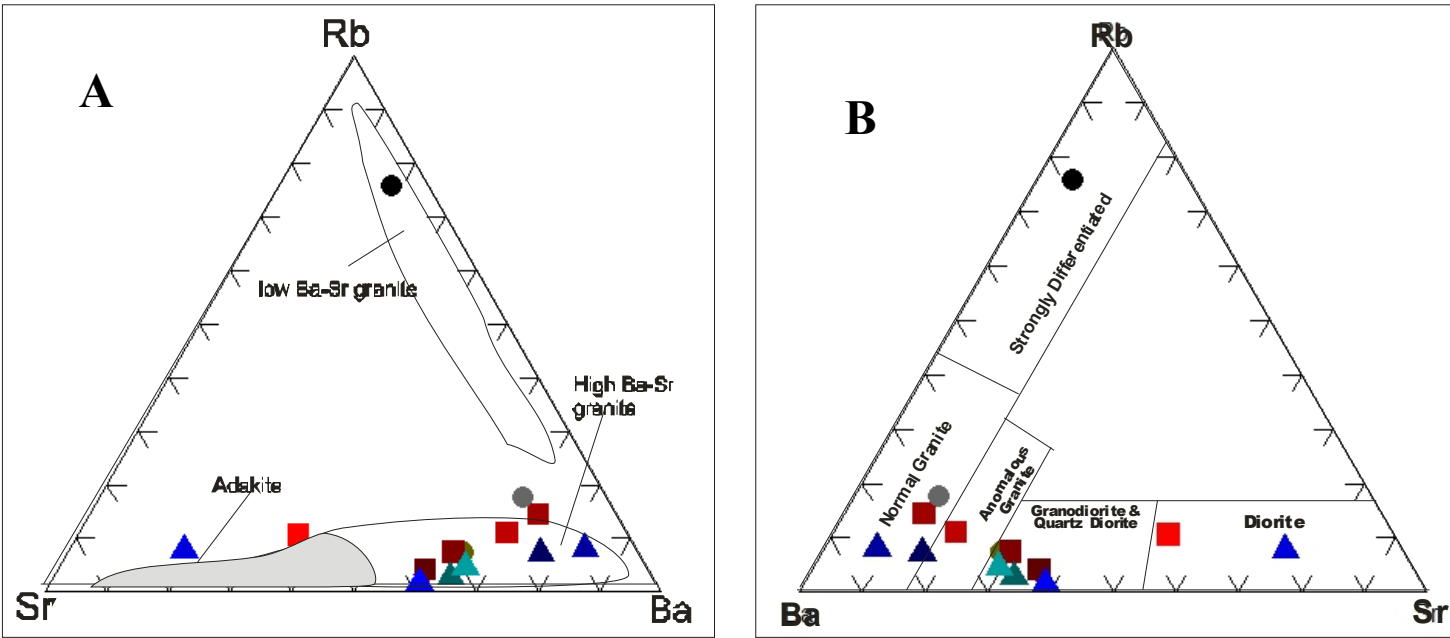

Banded Gneiss (Paleosome)

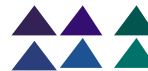

Granite Gneiss (Paleosome)

Granite (leucosome)

Fig. 11: Sr-Rb-Ba ternary plot after Tarney and Jones (1994) illustrating the high Ba-Sr nature of migmatites, banded and granitic gneiss in Kushaka schist belt. And Rb-Ba-Sr ternary diagram showing the distribution of the granites and the granodiorite in the study area (after El Bouseily and El Sokkary, 1975).

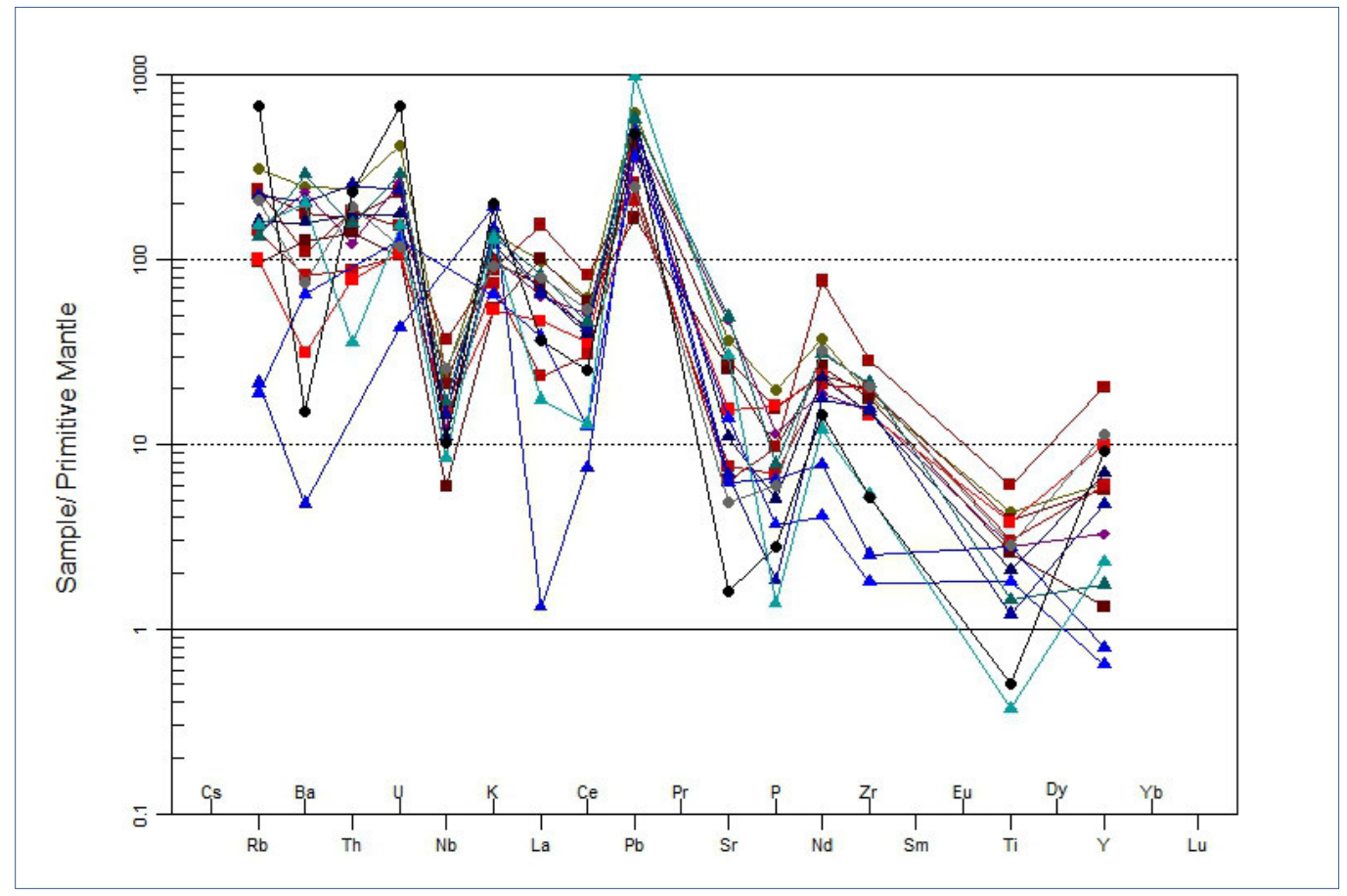

Fig. 12: Mantle-normalized multi-element diagram Kushaka and Birnin Gwari schist belts Granitoids with IAB signature (Sun and McDonough, 1989) (Symbols as in Fig. 3). 


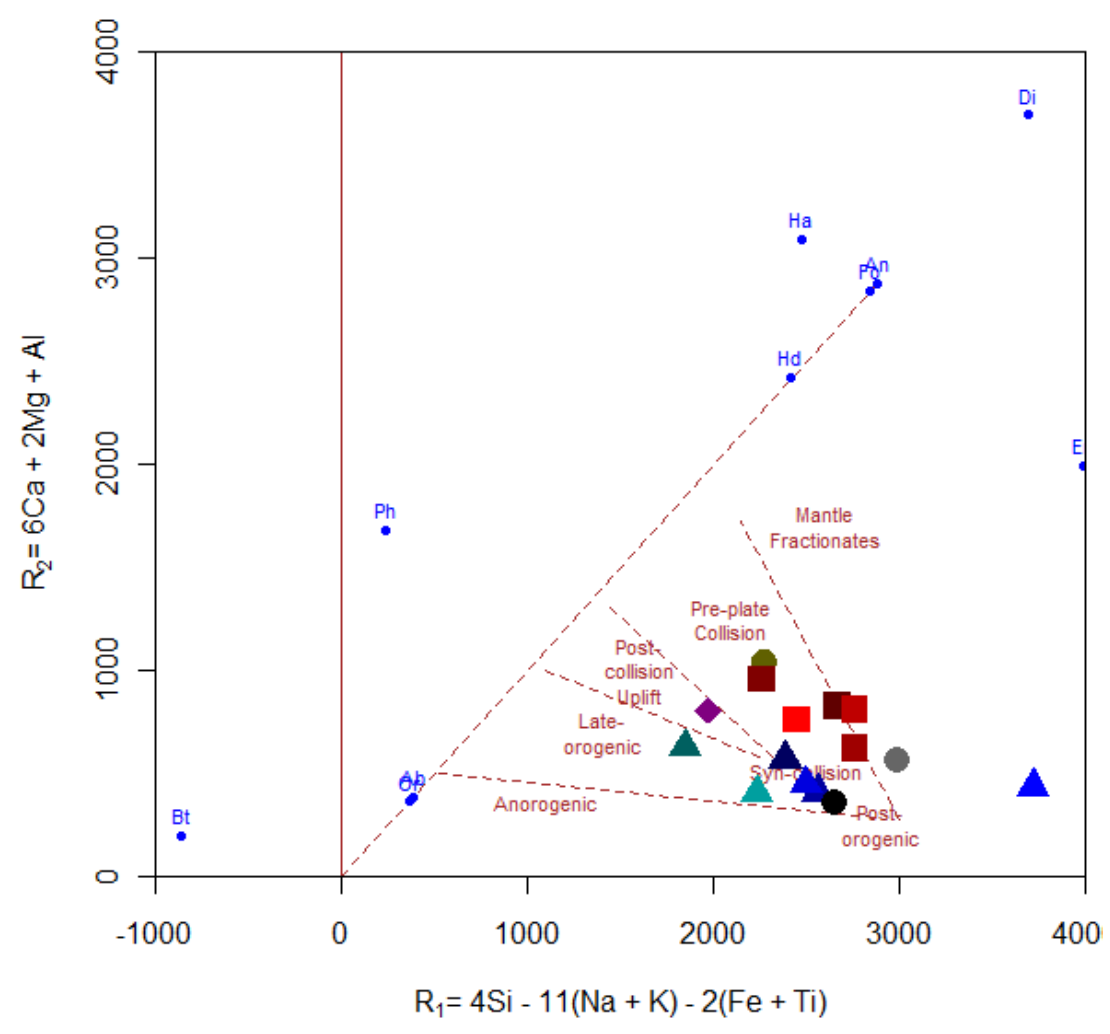

Fig. 13: Tectonic discrimination diagram (after Batchelor and Bowden, 1985), showing the distribution of the banded and granite gneiss within mantle fractionates, pre-plate collision, syn-collision and post-collision uplift fields (Symbols as in Fig. 3).
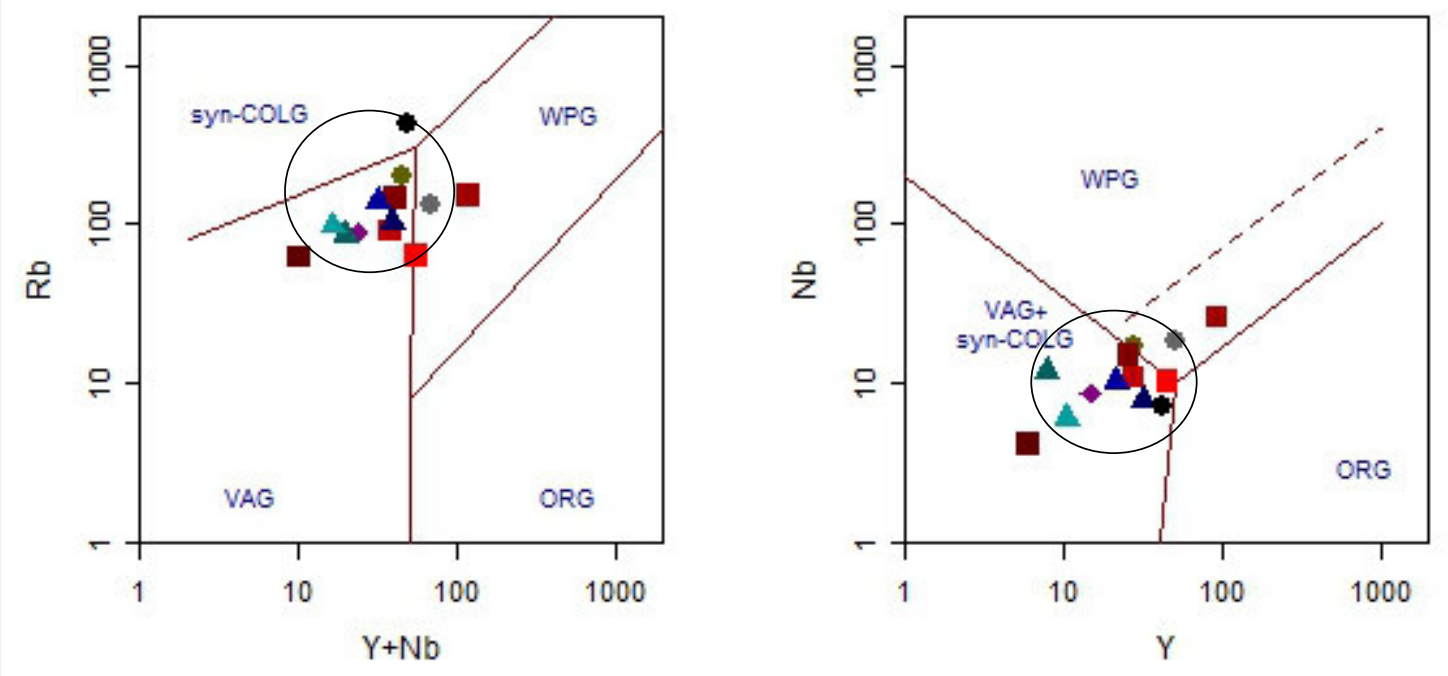

Fig 14: Tectonic discrimination diagram (after Pearce et al., 1984) showing the distribution of the banded and granite gneiss within the field of volcanic arc and post-collision granites (in black circle) (Symbols as in Fig. 3). 


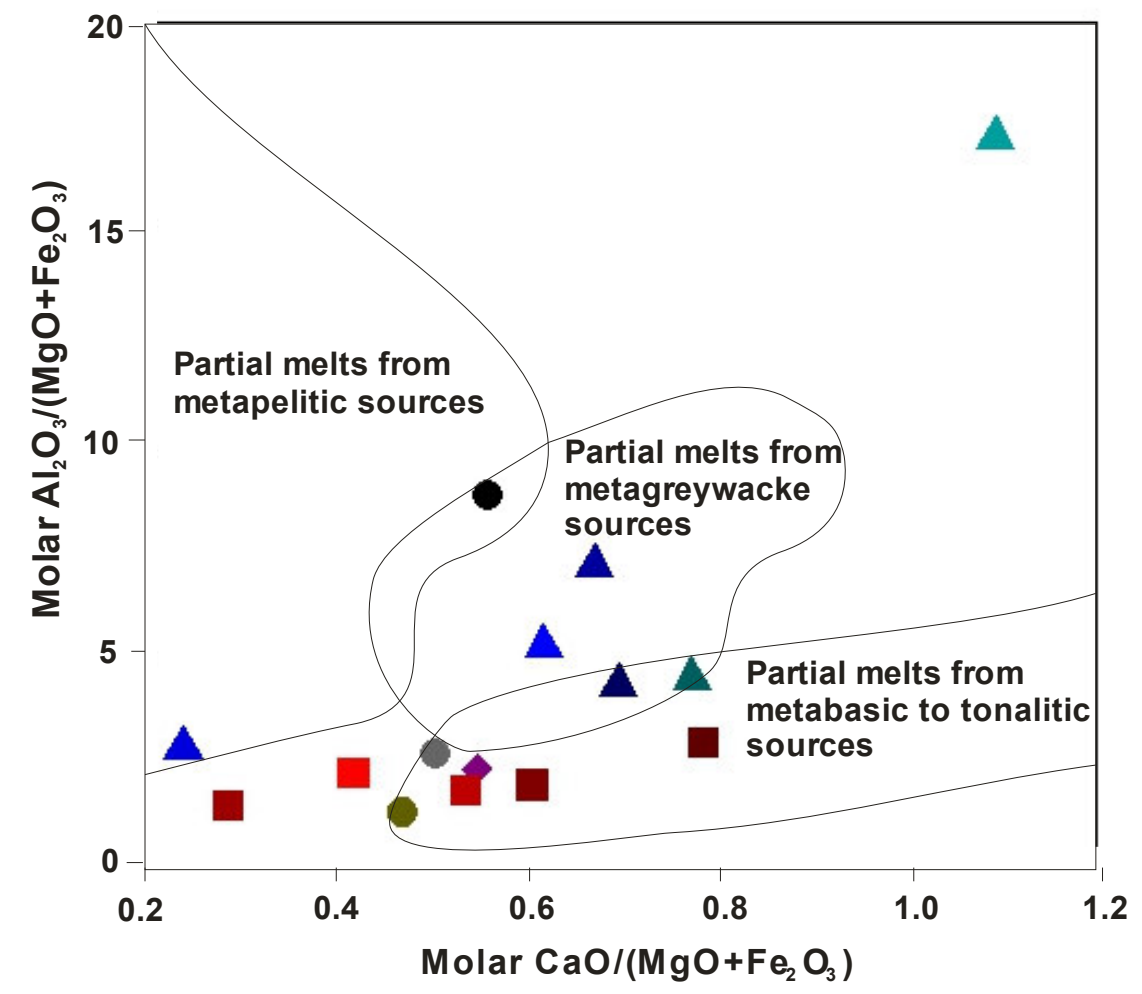

Fig. 15: Plots of molar $\mathrm{Al}_{2} \mathrm{O}_{3} /\left(\mathrm{MgO}+\mathrm{Fe}_{2} \mathrm{O}_{3}\right)-\mathrm{CaO} /\left(\mathrm{MgO}+\mathrm{Fe}_{2} \mathrm{O}_{3}\right)$ diagram (Altherr et al., 2000), of banded and granite gneiss with composition fields of partial melts deriving from experimental dehydratation-melting of various source rocks (Wolf and Wyllie, 1994, Gardien et al., 1995, Partino Douce and Beard, 1995; Partino Douce and Beard, 1996 and Singh and Johanneses, 1996) (Symbols as in Fig. 3).

Table 1: Major oxides composition of banded and granitic gneisses rocks in northern part of Kushaka schist belt (all values are in wt \%).

\begin{tabular}{|c|c|c|c|c|c|c|c|c|c|c|c|c|c|c|c|}
\hline Sample & $\frac{\mathrm{KD}}{\underline{1}}$ & $\frac{\text { KTN }}{2}$ & KGD3 & KGD4 & $\underline{\text { KGD5 }}$ & $\underline{\text { KGD6 }}$ & KGD7 & $\underline{\mathrm{KGn} 8}$ & $\underline{\mathrm{KGn} 9}$ & $\frac{\mathrm{KGn}}{10}$ & $\frac{\mathrm{KGn}}{\underline{11}}$ & $\frac{\mathrm{KGn}}{\underline{12}}$ & $\frac{\mathrm{KGn}}{\underline{13}}$ & $\frac{\mathrm{KGr}}{14}$ & $\frac{\mathrm{KGr}}{15}$ \\
\hline & \multicolumn{7}{|c|}{ Paleosome } & \multicolumn{6}{|c|}{ Granite Gneiss } & \multicolumn{2}{|c|}{ Leucosome } \\
\hline $\mathrm{SiO}_{2}$ & 60.77 & 64.45 & 67.98 & 63 & 67.11 & 66.81 & 65.24 & 70.49 & 74.42 & 70.74 & 77.53 & 67.81 & 74.89 & 73.61 & 75.44 \\
\hline $\mathrm{TiO}_{2}$ & 0.93 & 0.6 & 0.56 & 0.84 & 1.3 & 0.65 & 0.82 & 0.45 & 0.26 & 0.6 & 0.39 & 0.31 & 0.08 & 0.62 & 0.11 \\
\hline $\mathrm{Al}_{2} \mathrm{O}_{3}$ & 13.5 & 15.55 & 15.54 & 15.34 & 12.87 & 14.33 & 15.99 & 14.21 & 13.2 & 13.68 & 12.65 & 15.34 & 15 & 12.9 & 12.99 \\
\hline $\mathrm{Fe}_{2} \mathrm{O}_{3}$ & 7.04 & 4.78 & 4.03 & 5.67 & 7.69 & 7.15 & 5.13 & 2.55 & 1.55 & 3.91 & 1.93 & 2.72 & 0.78 & 4.08 & 1.32 \\
\hline $\mathrm{Mn} 0$ & 0.12 & 0.11 & 0.04 & 0.11 & 0.17 & 0.18 & 0.07 & 0.09 & 0.05 & 0.04 & 0.03 & 0.03 & 0.01 & 0.08 & 0.03 \\
\hline $\mathrm{Mg} 0$ & 4.2 & 2.07 & 1.36 & 2.53 & 1.71 & 1.11 & 2.31 & 0.79 & 0.31 & 1.1 & 0.52 & 0.75 & 0.09 & 0.9 & 0.16 \\
\hline $\mathrm{CaO}$ & 5.2 & 3.71 & 4.22 & 4.93 & 2.62 & 4.38 & 3.06 & 2.31 & 1.24 & 1.15 & 1.5 & 2.67 & 0.95 & 2.48 & 0.82 \\
\hline $\mathrm{Na}_{2} \mathrm{O}$ & 1.67 & 4.12 & 3.83 & 3.03 & 2.42 & 2.73 & 3.87 & 3.92 & 3.71 & 2.09 & 2.63 & 4.63 & 5.15 & 3.21 & 2.54 \\
\hline $\mathrm{K}_{2} \mathrm{O}$ & 4.18 & 3.09 & 1.64 & 2.97 & 2.66 & 2.23 & 1.6 & 3.6 & 4.42 & 5.81 & 1.93 & 4.06 & 3.87 & 2.79 & 6.13 \\
\hline $\mathrm{P}_{2} \mathrm{O}_{5}$ & 0.43 & 0.25 & 0.21 & 0.34 & 0.21 & 0.15 & 0.35 & 0.11 & 0.04 & 0.14 & 0.08 & 0.17 & 0.03 & 0.13 & 0.06 \\
\hline LOI & 0.66 & 0.39 & 0.69 & 0.92 & 0.48 & 0.26 & 1.09 & 0.59 & 1.01 & 0.56 & 1.04 & 0.36 & 0.4 & 0.39 & 0.27 \\
\hline Total & 98.7 & 99.1 & 100.1 & 99.68 & 99.24 & 99.98 & 99.53 & 99.11 & 100.2 & 99.82 & 100.23 & 98.85 & 101.25 & 101.19 & 99.87 \\
\hline $\mathrm{K}_{2} \mathrm{O} / \mathrm{Na}_{2} \mathrm{O}$ & 2.5 & 0.75 & 0.42 & 0.98 & 1.01 & 0.81 & 0.41 & 0.91 & 1.19 & 2.77 & 0.73 & 0.87 & 0.75 & 0.86 & 2.41 \\
\hline $\mathrm{Fe}_{2} \mathrm{O}_{3} / \mathrm{MgO}$ & 1.6 & 2.3 & 2.96 & 2.24 & 4.49 & 6.44 & 2.22 & 3.22 & 5 & 3.55 & 3.71 & 3.6 & 8.6 & 4.53 & 8.25 \\
\hline
\end{tabular}


Table 2: Trace elements composition of the banded and granitic gneiss in northern part of Kushaka schist belt (all values are in in ppm)

\begin{tabular}{|c|c|c|c|c|c|c|c|c|c|c|c|c|c|c|c|}
\hline$\underline{\text { Samp }}$ & KD1 & $\underline{\mathrm{KTN} 2}$ & $\underline{\text { KGD3 }}$ & $\underline{\mathrm{KGD} 4}$ & $\underline{\text { KGD5 }}$ & $\underline{\text { KGD6 }}$ & $\underline{\text { KGD7 }}$ & $\underline{\mathrm{KGn} 8}$ & $\underline{\mathrm{KGn} 9}$ & $\underline{\mathrm{KGn} 10}$ & $\underline{\text { KGn11 }}$ & $\underline{\mathrm{KGn} 12}$ & $\underline{\mathrm{KGn} 13}$ & $\frac{\mathrm{KGr}}{\underline{14}}$ & $\frac{\mathrm{KGr}}{\underline{15}}$ \\
\hline & \multicolumn{7}{|c|}{ Paleosome } & \multicolumn{6}{|c|}{ Granite Gneiss } & \multicolumn{2}{|c|}{ Leucosome } \\
\hline As & 0.8 & 2.4 & 4 & 0.2 & 2.4 & 3.8 & 2.8 & 2.5 & 2.9 & 3.8 & $<1$ & 1.1 & 1.8 & 4.6 & 2.2 \\
\hline $\mathrm{Ba}$ & 1723.3 & 1616.4 & 886.2 & 1247.3 & 764.7 & 572.3 & 217.5 & 1107.8 & 1445.5 & 33.3 & 453.9 & 2013.3 & 1408.4 & 519.8 & 104.5 \\
\hline $\mathrm{Ce}$ & 110 & 89.3 & 104.7 & 73.4 & 145.9 & 54.4 & 63.1 & 69.9 & 75.9 & 13.2 & 22.3 & 81.5 & 22.8 & 95.3 & 44.4 \\
\hline $\mathrm{C}_{0}$ & 51.4 & 66.4 & 72.3 & 41.9 & 54.6 & 51.3 & 40.9 & 48.7 & 67.7 & 2.4 & 3.5 & 92.6 & 44.9 & 67.2 & 56.7 \\
\hline $\mathrm{Cr}$ & 132.3 & 50.3 & 14.1 & 43.6 & 38.7 & 22.3 & 89.2 & 7.4 & 3.7 & 10.6 & 12.4 & 15.1 & 12.8 & 14.4 & 7.8 \\
\hline $\mathrm{Cu}$ & 19.2 & 15.8 & 11.8 & 17.6 & 27.3 & 17.3 & 27.7 & 5.1 & 13.7 & 209.9 & 218.5 & 9.1 & 6 & 11 & 6.4 \\
\hline $\mathrm{Ga}$ & 18.4 & 20.4 & 16.3 & 19.1 & 19.5 & 17.3 & 17.5 & 14.3 & 11.4 & 3.3 & 3.8 & 24.5 & 15.5 & 17.4 & 13.7 \\
\hline $\mathrm{La}$ & 67.1 & 43.4 & 69 & 49.4 & 105.9 & 16.1 & 31.9 & 46.5 & 44.4 & 0.9 & 26.2 & 56.7 & 12 & 54.4 & 25.1 \\
\hline Mo & 0.1 & 0.1 & $<1$ & $<1$ & 2.2 & 0.3 & 0.3 & 0.1 & 0.3 & $<1$ & $<1$ & $<1$ & $<1$ & 0.3 & 0.1 \\
\hline $\mathrm{Nb}$ & 17.4 & 8.7 & 4.2 & 15.1 & 26.3 & 11 & 10.4 & 7.8 & 10.3 & $<1$ & $<1$ & 12 & 6 & 18.3 & 7.3 \\
\hline $\mathrm{Nd}$ & 50.4 & 25.7 & 35.7 & 32 & 103.6 & 28.6 & 31.9 & 31.1 & 23.8 & 10.5 & 5.5 & 41.6 & 16.3 & 43.7 & 19.4 \\
\hline $\mathrm{Ni}$ & 59.3 & 15.9 & 4.2 & 6.7 & 14.3 & 5.6 & 29 & 0.9 & 1.2 & 1.8 & 4 & 2.2 & 1.5 & 5 & 2 \\
\hline $\mathrm{Pb}$ & 44.6 & 33.5 & 11.9 & 29.4 & 18.3 & 14.9 & 25.3 & 41 & 41.1 & 35.3 & 25.6 & 41 & 70.3 & 17.6 & 33.9 \\
\hline $\mathrm{Rb}$ & 198.4 & 89 & 61.6 & 146.8 & 151.4 & 90.6 & 63.7 & 102.6 & 140.9 & 13.6 & 12 & 85 & 97.7 & 132.8 & 430.1 \\
\hline $\mathrm{Sc}$ & 11.6 & 7.8 & $<1$ & 5.5 & 17.7 & 12.3 & 14.6 & 7.4 & 1 & $<1$ & $<1$ & 2 & 0.8 & 6.6 & 4.7 \\
\hline $\mathrm{Sn}$ & 8.4 & 7.8 & 4.7 & 8.2 & 8.1 & 3.8 & 3.8 & 5.9 & 8.2 & 38.6 & 30.6 & 8.4 & 6.4 & 7.9 & 10 \\
\hline $\mathrm{Sr}$ & 763.7 & 990.5 & $\begin{array}{l}538.9 \\
\end{array}$ & 597.9 & 133.6 & 160.2 & 324.9 & 230.7 & 143.4 & 131.2 & 290.8 & 1027.9 & 631.7 & 102.8 & 33.4 \\
\hline $\mathrm{Ta}$ & $<1$ & $<1$ & $<1$ & $<1$ & $<1$ & $<1$ & $<1$ & $<1$ & $<1$ & $<1$ & $<1$ & 0.5 & $<1$ & 0.1 & $<1$ \\
\hline Th & 20.6 & 10.4 & 11.9 & 14.1 & 15.6 & 7.5 & 6.6 & 14.8 & 21.7 & $<1$ & $<1$ & 13.2 & 3 & 16.6 & 19.9 \\
\hline $\mathrm{U}$ & 8.7 & 5.5 & 2.2 & 4.9 & 3.2 & 2.2 & 2.3 & 3.7 & 5 & 0.9 & 2.7 & 6.1 & 3.2 & 2.5 & 14.2 \\
\hline $\mathrm{V}$ & 160.8 & 86.1 & 78.3 & 118.8 & 113.2 & 60 & 114.2 & 20.7 & 10.1 & 2.6 & 4 & 31.4 & 8.8 & 37.5 & 6.7 \\
\hline W & 177.7 & 292.6 & 374.8 & 156.5 & 246.6 & 256.2 & 172.5 & 254.8 & 367.4 & $<1$ & 2.3 & 195 & 275.5 & 361 & 394.8 \\
\hline$Y$ & 27.5 & 14.9 & 6 & 25.9 & 93.1 & 27.4 & 45.3 & 31.6 & 21.5 & 3.6 & 2.9 & 7.9 & 10.5 & 51.2 & 41.9 \\
\hline $\mathrm{Zn}$ & 87 & 76.9 & 51.7 & 87.2 & 88.3 & 75 & 65.8 & 54 & 29.6 & 43.3 & 685.6 & 133.4 & 23.7 & 36.9 & 18.8 \\
\hline $\mathrm{Zr}$ & 204.6 & 169.4 & 197 & 221.6 & 318.4 & 226.4 & 160.9 & 166.4 & 175.4 & 28.2 & 20 & 240.6 & 59.6 & 227.5 & 57.3 \\
\hline
\end{tabular}

